\title{
ERISA's Fundamental Contradiction: The Exclusive Benefit Rule
}

\author{
Daniel Fischel $\uparrow$ \\ John H. Langbein ††
}

The comprehensive federal scheme for regulating pension and other employee benefit plans, ERISA, ${ }^{1}$ is approaching its fifteenth anniversary. ERISA has attracted a large administrative gloss and a burgeoning case law. Experience has begun to show the effects of the statute.

Parts of ERISA appear to have worked smoothly. The reporting and disclosure provisions ${ }^{2}$ that were a central goal of the legislation have been implemented without much ruckus. Another major goal of the statute, the vesting scheme that restricts the forfeiture of pension benefits, has also proved easy to institute. ${ }^{3}$ The disclosure and vesting rules have produced scant litigation.

Other parts of ERISA have become much more problematic. The overbroad preemption provision ${ }^{4}$ has wreaked aimless interference upon state regulation of areas such as health insurance

$\dagger$ Professor of Law and Business, University of Chicago Law School and Graduate School of Business.

†† Max Pam Professor of American and Foreign Law, University of Chicago Law School. The authors wish to acknowledge the financial support of the John M. Olin Foundation and the University of Chicago Law and Economics Program. We are grateful to learned audiences who reacted to this paper in earlier versions at law school workshops at Columbia, the University of Virginia, and Yale. We acknowledge with thanks suggestions and comments from Walter Blum, Richard Buxbaum, Maureen Gorman, Morton Klevan, Fred McChesney, Geoffrey Miller, Jeffrey Sherman, Jeff Strnad, and Alan O. Sykes.

Professor Fischel testified as an expert witness in two of the cases discussed in this article, Donovan $v$ Bierwirth and Leigh $v$ Engle. His testimony dealt mainly with measureof-damage issues, as opposed to the underlying liability issues canvassed in this article. The views expressed here are solely those of the authors.

${ }^{1}$ Employee Retirement Income Security Act of 1974, Pub L No 93-406, 88 Stat 829 (1974), codified as amended primarily in 29 USCS $\$ 1001$ et seq (1982 \& Supp 1988).

2 ERISA $\S 101(a)$ et seq, 29 USCS $\S$ 1021(a) et seq.

s Id $\$$ 203(a) et seq, 29 USCS $\$ 1053$ et seq (Supp 1988); Internal Revenue Code (IRC) $\S 411,26$ USCS § 411 (1982 \& Supp 1988). The Tax Reform Act of 1986, amending ERISA, shortened the vesting periods. It would be a mistake to conclude, however, that forfeitures were widespread prior to ERISA. See Richard A. Ippolito, A Study of the Regulatory Effect of the Employee Retirement Income Security Act, $31 \mathrm{~J} \mathrm{~L}$ \& Econ 85, 87-98 (1988).

- ERISA § 514, 29 USCS § 1144. 
that are quite peripheral to pension policy. Neither a substantial string of Supreme Court cases nor occasional Congressional repair has been able to cure the mess. ${ }^{5}$ Another well known instance of statutory shortsightedness is ERISA's effort to regulate the financial affairs of multiemployer plans. The 1974 legislation insisted on covering these plans without working out the principles, which Congress had to supply by amendment in $1980 .{ }^{6}$ The 1980 amendment imposed unexpected and dismaying retroactive liabilities on employers. ${ }^{7}$ Although the Supreme Court has mostly sustained the constitutionality of the scheme, ${ }^{8}$ employer resistance to participation in multiemployer plans has increased, and there is reason to think that the legislation may ultimately be seen to have doomed the multiemployer system. Yet another instance of serious disorder in ERISA is the insurance system that protects workers' pension benefits in the event that a plan defaults. ${ }^{9}$ Because the program rewards moral liazard, ${ }^{10}$ the Pension Benefit Guaranty Corporation (the federal insurer whose duty is to suffer the consequences) has amassed a deficit that is growing by billions ${ }^{11}$ and that makes the

- See the most recent case, Mackey v Lanier Collections Agency \& Service, 108 S Ct 2182 (1988), which canvasses the prior case law. For a convenient account of the two legislative amendments to ERISA's preemption provision, see Leon E. Irish and Harrison J. Cohen, ERISA Preemption: Judicial Flexibility and Statutory Rigidity, 19 U Mich J L Ref 109, 148-56 (1985).

- Multiemployer Pension Plan Amendments Act of 1980, Pub L No 96-364, 94 Stat 1208 , codified at numerous places throughout 29 USCS $\$ \S 1001$ et seq.

' See generally Frank Cummings and Alicia M. Kershaw, Withdrawal Liability Under the Multiemployer Pension Plan Amendments Act of 1980, 40 New York University Institute on Federal Taxation \$ 12.01 at 12-1 (1982 ERISA Supp).

${ }^{8}$ Connolly v. Pension Benefit Guaranty Corp., 475 US 211 (1986); Pension Benefit Guaranty Corp. v. Gray, 467 US 717 (1984). The specific retroactive liability upheld as constitutional in Gray was suhsequently eliminated by Congress in the Tax Reform Act of 1984, Pub L No 98-369, $\$ 558,98$ Stat 494, 899, (1984), codified at 29 USCS $\$ 1381$ and 26 USCS $\S 401$ (Supp 1988). See, I.A.M. Nat. Pension Fund v Allied Corp., 596 F Supp 481, 482 (D DC 1984), noting that "[t]he effect of the 1984 Act is to moot the decision in Gray." Other retroactive parts of the 1980 amendments were not affected by the Tax Reform Act.

The Third Circuit held a piece of the 1980 Act unconstitutional in United Retail \& Wholesale Employees v Yahn \& McDonnell, Inc., 787 F2d 128 (3d Cir 1986). The Supreme Court affirmed the result without opinion on a 4-4 vote, sub nom Pension Benefit Guaranty Corp. v. Yahn \& McDonnell, Inc., 107 S Ct 2171 (1987).

${ }^{\circledR}$ ERISA's Title IV, $\S 4001$ et seq, 29 USCS § 1301 et seq.

${ }^{10}$ Mainly, because ERISA's funding rules allow new liabilities to be created and amortized over a thirty year period, $\S 302$ (b)(2)(B)(iii), 29 USCS $\S 1082$ (b)(2)(B)(iii), while the Pension Benefit Guarantee Corporation ('PBGC') becomes liable for these promised benefits over five years (subject to certain restrictions and ceilings). ERISA § 4022 (b)(1), 29 USCS $\S$ $1322(\mathrm{~b})(1)$.

"In November 1986 the executive director of the PBGC estimated this deficit at between $\$ 2.3$ and $\$ 2.4$ billion and predicted that it would exceed $\$ 4$ billion by the end of 1987 . EBRI (Employee Benefit Research Institute), PBGC's \$4 Billion Deficit, 7 Employee Bene- 
program inherently unstable.

ERISA fiduciary law has not been widely reckoned to be on the list of ERISA's major blunders. In the present article we show that it belongs there. We observe that the central concept of ERISA fiduciary law, the exclusive benefit rule, misdescribes the reality of the modern pension and employee benefit trust. We show that the contradictions of the exclusive benefit rule bedevil a remarkable array of the main issues in modern pension trust administration: takeover cases, social investing, employee stock ownership schemes, asset reversions from terminated plans, and judicial review of benefit denials and other plan decisions. We emphasize that the mess in ERISA fiduciary law cannot be ameliorated until courts and other decision makers recognize the multiplicity of interests that inhere in the modern pension and employee benefit trust. We point to the familiar trust law concept of the duty of impartiality as a likely doctrinal rubric for taking account of this multiplicity of interests.

Section I of the article discusses the trust law antecedents of fiduciary duties under ERISA. Section II briefly describes the typology of pension and employee benefit plans. Section III examines the underlying tensions between trust law and fiduciary duty law. The remainder of the article examines a number of issues that have arisen as a result of these tensions.

\section{The Trust Law Antecedents of Fiduciary Duties under ERISA}

The main fiduciary provisions of ERISA have remained unaltered since Congress enacted the statute in 1974. Section 403 imposes a rule of mandatory trusteeship. Apart from plan assets that take the form of insurance, "all assets of an employee benefit plan shall be held in trust . ..."12

Pension and other employee benefit funds had been shaped in the juridical form of the trust for decades before 1974. The TaftHartley Act mandated the trust form for multiemployer plans in 1947..$^{13}$ Since 1921, the Internal Revenue Code has insisted upon the use of the trust as a condition of what we now call "qualifying"

fit Notes 9 (Dec 1986) (edited remarks of Kathleen Utgoff made at EBRI conference, Nov 1986).

12 ERISA \& 403(a), 29 USCS \& 1103(a).

13 Labor Management Relations (Taft-Hartley) Act, § 302(c)(5), 29 USCS § 186(c)(5) (1982 \& Supp 1988). 
a pension plan for tax benefits. ${ }^{14}$

The drafters of ERISA intended to "apply rules and remedies similar to those under traditional trust law to govern the conduct of fiduciaries."16 The heart of ERISA fiduciary law is section 404(a)(1), which contains three main subsections. ${ }^{16}$ Subsection A contains the exclusive benefit rule, subsection B imposes the "prudent man" standard of care for trust administration, and subsection $\mathrm{C}$ requires plan investments to be diversified. Each of these provisions transposes to pension law a major principle of trust law. The duty of prudent investing, the duty to diversify investments, and the duty of prudent administration are familiar standards of trust law. ${ }^{17}$

ERISA's exclusive benefit rule, which is the focus of this article, imports into pension fiduciary law one of the most fundamental and distinctive principles of trust law, the duty of loyalty. As explained in the Restatement of Trusts, the duty of loyalty places "the trustee ... under a duty to the beneficiary to administer the trust solely in the interest of the beneficiary." 18 The ERISA version states that the fiduciary "shall discharge his duties with respect to a plan solely in the interest of the beneficiaries and ... for the exclusive purpose of ... providing benefits to participants and their beneficiaries."19 In ERISA argot this "solely-in-the interest/ exclusive-purpose-of-[benefiting]" language of section 404(a)(1)(A) is compressed as the "sole interest/exclusive purpose" or sometimes simply the "exclusive benefit" rule. $^{20} \mathrm{~A}$ related provision,

14 Revenue Act of 1921, ch 136, § 219(f), Pub L No 42-98, 42 Stat 227, 247 (1921). The modern version is IRC $\S 401(\mathrm{a}), 26$ USCS $\S 401$ (a). As under ERISA $\S 403$ (a), so under IRC $\S \S 403(a)$ and $404(a)(2)$, the requirement of mandatory trusteeship does not pertain to a plan funded exclusively by insurance or annuity contracts.

${ }^{16}$ Conference Report on HR 2, Pension Reform, HR Rep No 93-1280, 93d Cong, 2d Sess 295, reprinted in 3 Legislative History of the Employee Retirement Income Security Act of 1974, 94th Cong, 2d Sess 4277, 4562 (1976) (prepared by the Subcommittee on Labor of the Committee on Labor and Public Welfare) ("Legislative History"). An earlier Senate report explained that ERISA's "fiduciary responsibility section, in essence, codifies and makes applicable to [pension plan] fiduciaries certain principles developed in the evolution of the law of trusts." Retirement Income Security for Employers Act of 1973, S Rep No 93127, 93d Cong, 1st Sess 29, reprinted in 1 Legislative History 587, 615.

${ }^{16}$ ERISA $\S 404(a)(1), 29$ USCS $\S 1104(a)(1)$.

${ }^{17}$ Restatement (Second) of Trusts $\S 174$ (prudent administration), $\S 227$ (prudent investing), and $\$ 228$ (diversification) (1959) ("Restatement").

18 Id $\S 170(1)$.

19 ERISA § 404(a)(1)(A)(i), 29 USCS § 1104(a)(1)(A)(i).

${ }^{20}$ The Conference Committee Report captions its discussion of the rule "Exclusive benefit for employees." Conference Report at 303, reprinted in 3 Legislative History at 4570 (cited in note 15). For similar usage in the courts, see, for example, Washington-Baltimore Newspaper Guild Local 35 v Washington Star Co., 555 F Supp 257, 259 (D DC 1983), aff'd 
ERISA's section 403(c)(1), contains another formulation of the exclusive benefit rule. This so-called "noninurement" rule requires that, subject to certain exceptions that become important in situations in which the pension plan is terminated, "the assets of a plan shall never inure to the benefit of any employer and shall be held for the exclusive purposes of providing benefits to participants in the plan and their beneficiaries . . ."21 Section 406 of ERISA, which forbids so-called "prohibited transactions," also implements the exclusive benefit rule by proscribing various types of self-dealing and other conflicts of interest. ${ }^{22}$

ERISA's exclusive benefit rule has a half-century of prehistory in other federal pension legislation. The Revenue Act of 1921 introduced an exclusive benefit requirement into the Internal Revenue Code. As a condition for qualifying a pension trust for tax deferral, the 1921 Act required that the employer create the trust "for the exclusive benefit of some or all of his employees ...."."s Section 401(a) of the present Code carries forward the tax law version of the exclusive benefit rule. Further, since 1947 the TaftHartley Act has required that contributions to the multiemployer plans regulated under that legislation be made "for the sole and exclusive benefit of the employees . . . and their families and dependents . . .."24

The tax law exclusive benefit rule has purposes broader than the duty of loyalty in trust law. A main theme of pension tax law is the so-called anti-discrimination norm, which seeks to condition the award of pension tax benefits upon broad pension coverage within the employer's workforce. ${ }^{25}$ The Internal Revenue Code's exclusive benefit rule reinforces the anti-discrimination norm when trust funds are used to benefit owners or other insiders. ${ }^{26}$ The exclusive benefit rule of the Taft-Hartley Act, by contrast, is meant, like the ERISA version, to implement trust law notions of the duty of loyalty. The Taft-Hartley rule has become the cornerstone of a

without opinion, 729 F2d 863 (DC Cir 1984).

${ }^{21}$ ERISA $\$ 403(c)(1), 29$ USCS $\$ 1103(c)(1)$. See section VIII of this article for a discussion of the conflict between the noninurement rule and the employer's undisputed power to recapture excess assets upon plan termination.

22 Id $\S 406,29$ USCS $\$ 1106$.

${ }^{23}$ Revenue Act of 1921, ch 136, § 219(f), Pub L No 42-98, 42 Stat 227, 247. See also note 14 and accompanying text.

${ }^{24}$ Labor Management Relations (Taft-Hartley) Act, §302(c)(5), 29 USCS § 186(c)(5).

${ }^{25}$ See generally Bruce Wolk, Discrimination Rules for Qualified Retirement Plans: Good Intentions Confront Economic Reality, 70 Va L Rev 419 (1984).

${ }^{28}$ For example, see Central Motor Co. v United States, 583 F2d 470, 488-91 (10th Cir 1978). 
huge case law, which ERISA now overlaps, dealing with judicial review of plan administration. ${ }^{27}$ For purposes of the present Article, we shall be concerned not with the tax law rule, but with the exclusive benefit rule of ERISA's fiduciary law.

The duty of loyalty is the centerpiece of the common law of trusts. The drafters of ERISA had special reason for thinking that the duty of loyalty belonged in pension fiduciary law. In the 1950s and 1960s, investigative hearings on the subject of labor union racketeering held under Senator John McClellan achieved immense notoriety. ${ }^{28}$ The corruption in the Teamsters union, including the looting of union-controlled pension and employee benefit funds, came to public attention..$^{29} \mathrm{By}$ mandating the trust form and transposing the duty of loyalty to pension law, the drafters of ERISA were able to institute a familiar regime to protect pension funds against internal defalcation. In the post-ERISA period, when cases of self-dealing have arisen, the exclusive benefit rule (buttressed by ERISA's ancillary procedural and remedial measures) has proved an effective corrective. ${ }^{30}$

The exclusive benefit rule works well enough against thieves and thugs, but the rule sweeps more broadly, and in the less dramatic settings the rule has proved more problematic. In many situations, the exclusive benefit rule, by oversimplifying the nature of these arrangements, has misdescribed the reality of the interests, misled the courts, induced inappropriate analysis, and produced improper results.

\section{Plan Typology}

The universe of pension and employee benefit plans that ERISA fiduciary law governs is large and complex. For purposes of the issues being canvassed in the present article, however, only the rudiments of plan typology need to be borne in mind.

${ }^{27}$ The plan administration cases are discussed in section $\mathrm{V}$ of this article.

${ }^{28}$ See, for example, The Craggy Man Who Took on the Labor Rackets, Newsweek 39 (April 8, 1957); Battle Over Teamster Funds: When Senators Asked Questions, This is What a Big Union Did, US News \& World Rep 89 (Feb 1, 1957); see also Victor in a $21 / 2$ Year Fight, US News \& World Rep 68 (Sept 14, 1959).

${ }^{29}$ See Michael S. Gordon, Overview: Why Was ERISA Enacted?, in The Employee Retirement Income Security Act of 1974: The First Decade, S Rep No 98-221, 98th Cong, 2d Sess 1, 10-11 (1984) (Information Paper Prepared for Use by the Special Committee on Aging, US Senate).

${ }^{30}$ For example, see Donovan v Mazzola, 716 F2d 1226 (9th Cir 1983). 


\section{A. Pension Plans and Welfare Benefit Plans}

ERISA makes a fundamental distinction between pension plans and welfare benefit plans. ${ }^{31} \mathrm{~A}$ pension plan envisions a program of savings during the worker's period of employment, followed by distribution to the worker and his spouse during their retirement. Such a program may endure for decades. By contrast, welfare benefit plans are conceived to be current expense undertakings; the liabilities arise more or less concurrently with the revenues. Welfare benefit plans include employer or union sponsored medical, disability, life insurance, childcare, vacation, unemployment, severance pay and similar schemes. ${ }^{32}$ Since these plans have not been thought to require long-term funding, ${ }^{33}$ they have been exempt from ERISA's funding and vesting rules. ${ }^{34}$ ERISA fiduciary law, however, applies both to pension and to welfare benefit plans. Especially in the voluminous ERISA case law dealing with judicial review of benefit denials and other plan decision making, ${ }^{35}$ welfare benefit and pension plans are treated indistinguishably.

\section{B. Single Employer Plans and Multiemployer Plans}

The typical pension or welfare benefit plan is operated by one employer for the employees of that firm. These so-called "single employer plans" may be the result of collective bargaining or may be sponsored by nonunionized firms. In some industries, however, particularly those in which employment patterns are episodic and in which multifirm or industry-wide collective bargaining is common (for example, the construction trades, entertainment, trucking, the needle trades), individual firms do not sponsor plans. Rather, the union takes the initiative through the collective bargaining process for establishing the pension and benefit plans, and numerous employers contribute to the union sponsored plan. Although the Taft-Hartley Act requires equal numbers of employer and union designated trustees on the board of such a multiemployer plan, union interests tend to prevail and multiemployer

${ }^{31}$ ERISA §§ 3(1)-(2), 29 USCS § 1002(1)-(2).

${ }^{32}$ Id $\S 3(1), 29$ USCS $\S 1002(1)$.

${ }^{33}$ Recent experience indicates that the line between pension and welfare benefits is not well drawn as it affects retiree medical plans. A plan that provides health benefits across a worker's retirement period is in truth a type of pension plan. On the difficulties besetting these plans, see generally Bruce D. Pingree, Current Issues in Termination and Modification of Welfare Plans, 14 Tax Manage Comp Plan J 311 (1986).

${ }^{34}$ ERISA §§ 301(1), 201(a)(1), 29 USCS §§ 1081(a)(1), 1051(1).

${ }^{36}$ See section $\mathrm{V}$. 
plans are often called union plans..$^{36}$

\section{Defined Contribution and Defined Benefit Plans}

Within the realm of pension plans, the crucial distinction is between defined contribution and defined benefit plans. ${ }^{37} \mathrm{~A}$ defined contribution plan is best analogized to a savings account. The plan calls for the establishment of a separate account for each employee. The employer must contribute to each account at a rate specified in the plan (for example, five percent of earnings, or forty cents per hour worked). Each account participates proportionately in the investment experience of the fund. When the employee retires, the size of his pension will depend entirely upon the size of his account. TIAA/CREF, the college teachers' pension plan, works on this principle; the familiar IRA account mirrors it. Another common variety of defined contribution plan is the profit-sharing plan, by which a firm allocates some fraction of earnings to individual accounts of participating employees. Yet another variety is the stock bonus plan, through which the firm contributes company shares rather than cash to the employees' accounts. ${ }^{38}$

The dominant form of pension plan is the defined benefit plan. ${ }^{39}$ In these plans, the employer (or other plan sponsor) promises to pay a retirement pension according to a formula that adjusts benefits based on such variables as the employee's length of service and final salary. ${ }^{40}$ The employer finances the plan by making regular contributions to the plan, in accord with actuarial projections of the sums needed to fund the promised pension level.

Defined contribution and defined benefit plans allocate investment risk oppositely. Under a defined contribution plan, the employee bears the burden of disappointing investment results and pockets the gains from good results. Under a defined benefit plan,

36 Labor Management Relations (Taft-Hartley) Act, § 302(c)(5)(B), 29 USCS §186 (c)(5)(B). For a further discussion of the union dominance in multiemployer plans, see text following note 113 .

${ }^{37}$ ERISA $\S \S 3(34)-(35), 29$ USCS $\S$ 1002(34)-(35).

${ }^{38}$ For further discussion of employee stock ownership, see section IX.

${ }^{39}$ Ippolito estimates that defined benefit plans held about 70 percent of private pension assets as of 1984. Richard A. Ippolito, Pensions, Economics and Public Policy 81 (Dow Jones-Irwin, 1986). See id at 103-05 for an account of the supposed advantages of defined benefit plans.

${ }^{10}$ For example, a typical defined benefit plan might calculate the pension as a certain percentage of the employee's average salary over his final five years of employment. The percentage is determined by multiplying the employee's years of service times a number such as two percent. Thus, in this example, a 30 -year employee would be entitled to a pension of 60 percent of his final average salary. 
the employer bears the investment risk. Since the employer has promised to provide benefits at a certain level, the employer remains liable to pay the benefits even if the fund turns up short. By the same token, when investments yield unexpectedly high returns, the employer's liability to contribute to the plan is correspondingly reduced.

Multiemployer pension plans straddle the line between defined contribution and defined benefit plans. From the standpoint of the employee the plan looks like a defined benefit plan, since the plan sets benefit levels that are not tied to individual accounts. From the employer's standpoint, however, the multiemployer plan looks like a defined contribution plan. The collective bargaining agreement fixes the amount the employer must contribute (for example, so many dollars per covered employee per month), typically without explicit connection to the plan's benefit levels. It is the trustee's job to align the benefit levels that the plan promises with the expected contribution levels. ${ }^{41}$

\section{Tensions Between Trust Law and ERISA Fiduciary Law}

Although ERISA's exclusive benefit rule originates in the trust law duty of loyalty, it is far from clear that the private gratuitous trust and the employee benefit plan are really comparable. In this section, we discuss differences between the ordinary trust and the pension trust. We suggest that these differences undercut the rationale for routine application of trust law rules to employee benefit plans. We also discuss the failure of ERISA to address the problem of conflicts among beneficiaries.

\section{A. Economic Perspectives on Trust Law Fiduciary Duties}

The essentials of the typical private trust are familiar enough. The owner of property, called the settlor of the trust, conveys property for the benefit of one or more beneficiaries to a third party, who serves as trustee. The trustee holds for the benefit of each beneficiary. This donative transfer could have been implemented as a simple gift, from settlor to beneficiary, but that is not quite what the settlor wanted. Often the beneficiary is (or, at a

41 The 1980 amendments to ERISA, cited in notes 6-8, impose on contributing employers a set of subsidiary liabilities for shortfalls in certain circumstances. These amendments make multiemployer plans look more like defined benefit plans from the employer's perspective since the employer now bears part of the risk of poor investments or excessive benefit payments. 
future time when the transfer takes effect, could turn out to be) a minor, an incompetent, a financially unsophisticated spouse, or somebody else to whom the settlor fears to transfer outright dominion of the property. The trust form allows the settlor to place active control of the property in the hands of an intermediary, the trustee, while still directing the benefit to flow to the persons who are in function donees.

The transferor might in theory design some such arrangement by contract. Such a contract would be a close substitute for the trust, but in practice the settlor usually ${ }^{42}$ prefers the trust form. ${ }^{43}$ A main reason for using the trust form is that it invokes a developed set of fiduciary rules that regulate the behavior of trustees. In addition to the duty of loyalty that prohibits self-dealing, trust law fiduciary rules regulate the compensation that trustees receive, prohibit delegation, and impose duties of prudence in investing and administration. ${ }^{44}$

The logic of imposing relatively strict fiduciary duties upon the trustee, especially the stringent duty of loyalty, follows directly from the distinctive characteristics of the trust relationship. The trust is frequently used as a governance mechanism in situations in which the settlor will be dead and in which there is a risk that the beneficiaries may be impaired or otherwise unsuited to administer the property. For precisely the reasons that inspire the use of a third party trustee, neither the transferror nor the beneficiaries are well situated to monitor closely the actions of the trustee.

The strict fiduciary duties of trust law act as substitutes for monitoring by the directly interested parties. The duty of loyalty is prophylactic; its purpose to deter the trustee from engaging in selfinterested conduct at the expense of the beneficiaries. The idea is to prevent misbehavior by erecting an irrebuttable presumption of

12 The most important exception occurs when the transferror arranges to "settle" life insurance proceeds for the beneficiaries by means of one of the standard life insurance settlement options. The transferror contracts with the company for the benefit of the beneficiaries. The contract form captures the different role of the intermediary. Unlike the stakeholding trustee who must segregate the transferred trust property, see Restatement $\S$ 179 (cited in note 17), the life insurance company is directly liable for the benefit levels that it guarantees. In lieu of the fiduciary safeguards of trust law, the insurance beneficiary has certain regulatory safeguards that reinforce market discipline in the industry.

${ }^{4}$ Indeed, the trust is such a fixture of Anglo-American law that we tend not to remember that it is "an institution unknown in civil-law countries." Donald T. Trautman and Emmanuel Gaillard, The Hague Conference Adopts a Convention for Trusts, 124 Trusts \& Estates 23, 23 (Feb 1985).

" Restatement $\$ 170$ (loyalty), 171 (nondelegation), 174 (prudent administration), 227 (a) (prudent investing) (cited in note 17). Compensation, id $\$ 242$, is largely regulated by individual state statutes. 
wrongdoing whenever the trustee engages in conflict tainted transactions. The trustee who deals with trust property for his own account is not allowed a defense even when the transaction was innocent or harmless to the beneficiaries. ${ }^{45}$ In such a situation, the rule of equity actually works to inflict rather than prevent unjust enrichment, because the trustee's gains are awarded to the beneflciaries even when not made at the beneficiaries' expense.

The justification is not simply that so harsh a rule deters, but that it deters at acceptable cost. The property of any one trust fund is minuscule compared to the universe of investment and entrepreneurial opportunity that the economy provides. Accordingly, to wall the trustee off from self-dealing with trust property is seldom an onerous burden.

The weakness of monitoring by interested parties may also help explain the nondelegation doctrine, ${ }^{46}$ which prevents the trustee from using substitutes to perform key trust responsibilities when the settlor is unable to consent. The difficulty of monitoring also sheds light on the duty of prudent investing, with its characteristic emphasis on low risk investments. ${ }^{47}$ Trust assets frequently constitute a large fraction of the beneficiaries' wealth. If in such cases the settlor could direct the trustee's investment strategy and continually monitor performance, the settlor would usually insist that the trust assets be invested cautiously, to ensure that the basic needs of the beneficiary (food, shelter, clothing, medical care, education, and so forth) are met. Since the departed settlor cannot continually assess the trustee's performance, a substitute monitoring device is required. The duty of prudence, by emphasizing low risk investing, serves this function.

The fiduciary rules imposed on trustees are not costless. Fiduciary duties restrict discretion. Thus, the rule against self-dealing prevents transactions between the trust and the trustee that might benefit both; the nondelegation doctrine restricts specialization; the duty of prudent investing causes some profitable opportunities to be ignored; limitations on compensation cause some qualified individuals to refuse to serve as trustees. In other settings, these trust law fiduciary duties would be too costly, and the law has developed differently. In corporate law, for example, managers are

15 For example, see Hartman v Hartle, 95 NJ Eq 123, 122 A 615 (Chanc 1923).

46 Restatement $\$ 171$ (cited in note 17). We imply no approval of the doctrine.

47 On the origins of the preoccupation with low risk investing in trust law, see John $\mathrm{H}$. Langbein and Richard A. Posner, Market Funds and Trust-Investment Law, 1976 Am Bar Found Res J 1, 3-6. 
also referred to as fiduciaries, yet self-dealing is not prohibited. Rather, interested director transactions are permitted, but subject to greater judicial scrutiny. Similarly, corporate law invites extensive delegation. Nor does the bias for low risk investing that distinguishes the trust law duty of prudence carry over to corporate law. Rather, the deferential standard of the business judgment rule effectively shields most decisions of corporate managers from judicial review. ${ }^{48}$

These weaker fiduciary constraints are appropriate in the corporate context because a developed set of monitoring mechanisms tends to align the interests of managers and investors. These mechanisms are both internal, such as scrutiny by outside directors and large shareholders; and external, such as the takeover market. Contrast the trust situation: it is difficult or impossible for the settlor or the beneficiaries to monitor the trustee, ${ }^{49}$ and there is no takeover market for trustees. In order to deter conduct by the fiduciary that is inconsistent with the wishes of the settlor (and inconsistent with the welfare of the beneficiaries), trust law imposes stricter fiduciary rules. These stricter rules substitute for the weaker private or market-type constraints.

The stricter fiduciary rules of trust law mimic the contractual terms that the settlors and trustees would have agreed upon if the costs of negotiating and enforcing such contracts were zero. ${ }^{50} \mathrm{By}$ serving as implied contractual terms, fiduciary rules reduce transaction costs and thus facilitate dispositions of property that might not have occurred in the absence of the trust scheme of governance.

Similarly, in the realm of pension or other benefit plans, it is impossible to foresee every change in circumstances that may affect the plan, hence the difficulty of specifying in advance by plan terms or other contractual provisions how conflicts should be resolved. Legal rules determine how conflicts will be resolved. The better these rules are able to approximate the bargain the parties would have struck had they been able to anticipate and resolve all the problems, the more willing the parties will be to establish such

48 For a discussion of the business judgment rule and fiduciary duties in corporate law, see Daniel R. Fischel and Michael Bradley, The Role of Liability Rules and the Derivative Suit in Corporate Law: A Theoretical and Empirical Analysis, 71 Cornell L Rev 261 (1986).

48 Unless, of course, the trust instrument retains for the settlor or grants to the beneficiaries the power to replace the trustee.

so See Frank H. Easterbrook and Daniel R. Fischel, Corporate Control Transactions, 91 Yale L J 698, 700-03 (1982), for discussion of fiduciary duties as implied contractual terms. 
plans.

\section{B. Fiduciary Duties and Employee Benefits Plans}

Significant differences exist between the private gratuitous trust and the universe of pension and employee benefit plans. These differences have powerful implications for delineating the appropriate fiduciary duties for trustees and other fiduciaries of employee benefit plans.

The settlor who creates an ordinary trust for the benefit of one or more beneficiaries is readily ascertainable. In employee benefit plans, by contrast, it is for many purposes impossible to distinguish the settlor from the beneficiary. Rather, because employee benefit plans are part of a total compensation package agreed upon by employer and employee, it is best for many purposes to conceive of employer and employee as both settlor and beneficiary.

In the jargon of benefits law, most plans are "noncontributory," meaning that the employer writes the checks to pay for most or all pension and welfare benefits. Nevertheless, these benefits are not free to employees. Employees pay for pension benefits in the form of lower wages. ${ }^{51}$ Thus, employees will bargain for plans only if the benefits anticipated exceed the income foregone. In this vital sense, each employee is, together with the employer, the settlor of his own pension and benefit plans. ${ }^{62}$

Pension and other benefit plans will not be established unless they are in the mutual interest of employers and employees. Plans are strictly voluntary arrangements. Neither ERISA nor the tax code nor the labor laws require the firm to offer any of these plans as a condition of employment. Vast numbers of firms, especially smaller firms in the retailing, service, and agricultural industries, have no plans or have skimpy ones. ${ }^{53}$

Among the mutual interests of employers and employees that lead to the creation of plans, two stand out. First, compensation in the form of pension benefits is tax advantaged. Most forms of contribution to pension accounts are tax deferred, meaning that income tax is paid not when the employee earns the money that is

s1 See generally Ronald G. Ehrenberg and Robert S. Smith, Modern Labor Economics: Theory and Public Policy 394-406 (Scott, Foresman, 3d ed 1988).

${ }^{32}$ There is an analogy to the incidence of Social Security contributions. While these contributions are nominally paid by employers, studies demonstrate that in the long run the burden of the payroll tax rests on labor. See Alicia H. Munnell, The Economics of Private Pensions 3 (Brookings Inst, 1982) (collecting studies).

ss Id at 199-201; see generally Emily S. Andrews, The Changing Profile of Pensions in America 47-113 (Employee Benefit Research Inst, 1985). 
contributed to his account, but years later when the money is drawn down for distribution, ${ }^{54}$ ordinarily during retirement. Furthermore, the investment yield on pension savings accrues and compounds on a tax deferred basis until distribution..$^{58}$ Because the tax laws create an incentive for tax sensitive employees to take compensation in the form of pension benefits, the employer can deliver and the employee can receive more value per dollar of compensation through pension benefits than through cash wages.

Tax advantages aside, benefit plans, especially pension plans, may reduce the overall cost of labor. For example, pension eligibility and forfeiture requirements, to the extent that ERISA still permits them, reduce employee turnover and thus enable employers to economize on recruitment and training costs. ${ }^{56}$ Similarly, group insurance plans, through which a firm buys life, health, accident, or other coverage for its workers and their dependents, offer significant economic advantages over individual policies, primarily by reducing sales, underwriting, and administrative costs. The gains from reduced labor costs as well as from the tax subsidy will be shared in some fashion by employers and employees. ${ }^{57}$

Because in this important sense the employer and the employee both benefit from the pension or welfare benefit plan, there is an obvious difficulty in interpreting the exclusive benefit rule. The plans are established for the mutual advantage of employer and employee, not for the exclusive benefit of one. The exclusive benefit rule on its face is inconsistent with the economic realities of the plans.

The simple trust law model of exclusive benefit does not, therefore, comport with the reality of the interests in employee benefit plans. In the private trust situation, the settlor's welfare is maximized if the beneficiaries capture all the benefits flowing from the trust. That is why the duty of loyalty requires the trustee to act in the exclusive interest of the beneficiaries. And because neither the settlor nor the beneficiaries may be able or suitable to monitor the actions of the trustee, trust law imposes strict fiduci-

${ }^{54}$ IRC $\S \S 402(a)(1), 404(a)(1)(A), 26$ USCS $\S \S 402(a)(1), 404(a)(1)(A)$.

${ }^{8 s}$ IRC $\S 501(a), 26$ USCS $\S 501(a)$; see the discussion in Ippolito, Pensions, Economics and Public Policy at 20-24 (cited in note 39).

se "[T]he benefit provisions of defined benefit formulas not only serve as a strong deterrent to retirement prior to the early retirement age [defined in the plan], but they serve as a remarkably strong deterrent to job switching, even at very young ages." David A. Wise, ed, Pensions, Labor, and Individual Choice 9 (Chicago, 1985).

${ }^{57}$ Precisely how the gains will be shared depends on the elasticities of the supply and demand for lahor. 
ary duties restricting the ability of the trustee to engage in conduct that might impair the interests of the beneficiaries and thus frustrate the intentions of the settlor.

In the employee benefit situation, the settlor's welfare is also maximized if the beneficiaries capture the benefits resulting from the trust. The difference is that employers and employees act in both capacities. The trust exists to maximize the joint welfare of both. Moreover, because the employer and the employees continually monitor the performance of the trustee of an employee benefit plan, ${ }^{58}$ there may be less need for strict fiduciary duties that limit the discretion of the trustee to engage in conduct that may be mutually beneficial to both groups.

Notwithstanding the continual monitoring of trustees by employers and employees, fiduciary rules are still important in regulating pension trustee behavior. In particular, the risk always exists that the trustee of an employee benefit plan will take self-interested action (for example, siphoning assets from the pension fund) that will operate to the detriment of the beneficiaries (employers and employees). Fiduciary rules (and criminal laws) deter this type of behavior; in the absence of such rules, the parties would have to devote additional resources to preventing and detecting the various forms of self-dealing.

\section{Conflicts among Beneficiaries}

In focusing on the overlap of employers' and employees' interests in pension and other employee benefit plans, we risk oversimplifying. Overlapping interests are not identical. There are indeed employer/employee conflicts; there are conflicts among employees; and there are conflicts with the federal insurance agency, the Pension Benefit Guaranty Corporation (PBGC), that, under Title IV of ERISA, guarantees most defined benefit pension promises. ${ }^{59} \mathrm{We}$ illustrate these conflicts by pointing to a pair of recurrent examples.

so While individual employees may find it difficult to monitor the performance of the plan, the same is not true for unions acting on behalf of employees. (There is a high correlation between plan coverage and unionization. Ippolito, Pensions, Economics and Public Policy at 189-90 (cited in note 39).) Moreover, the reporting and disclosure provisions in Title I, Part I of ERISA are designed to facilitate monitoring.

ss For a succinct account of how financial risk incides among workers, the firm, and the PBGC see Munnell, The Economics of Private Pensions at 144-46 (cited in note 52). For an extensive analysis of this matter, see Jack L. Treynor, Patrick J. Regan, \& William W. Priest, Jr., The Financial Reality of Pension Funding Under ERISA (Dow Jones-Irwin, 1976). 


\section{Younger workers versus older.}

Employees have diverse interests, and conflicts may arise among various subclasses. Consider, for example, the decision about what fraction of employees' compensation should be devoted to pension saving. There is no reason to think that all employees will share a common viewpoint on that issue. Younger employees who are paid on entry-level pay scales and who have houses to buy and families to launch may see retirement as a distant blip on the horizon. By contrast, senior employees who are at the peak of their earning power, who are taxed in higher brackets on current income, and who see themselves only a short distance from retirement, are likely to exhibit a greater proclivity for tax advantaged pension saving. Indeed, one of the most insightful explanations for the prevalence of the defined benefit pension plan is Jeremy Bulow's suggestion that, because the time value of money skews the benefits in these plans toward older workers, this type of plan accommodates within a seemingly uniform benefit schedule the conflicting preferences of younger workers for lower levels of pension saving and older workers for higher levels. ${ }^{60}$

The choice between retirement security and employment security heightens the conflict of interest among subclasses of plan participants. Retirees present the extreme case. They face no tradeoff between pension benefits and employment compensation. From their perspective, pension benefits always prevail, even though some current workers might lose their jobs as a result. The same is not true for youthful employees. Not only do they have a smaller percentage of their wealth tied up in the pension plan, but they will also be more concerned about job security than about pension benefits. The young employee's income stream from employment far exceeds that from future pension income, especially when both streams are properly discounted for the time value of money. Thus, young employees may support the use of plan assets to enhance job security by, for example, having the pension fund buy or vote employer stock to fend off a hostile acquiror who has pledged to reduce labor costs. Younger workers would be likely to favor such a policy even if it were to cause the value of the pension

${ }^{60}$ See Jeremy I. Bulow, The Effect of Inflation on the Private Pension System, in Robert E. Hall, ed, Inflation: Causes and Effects 123, 134-35 (Chicago, 1982). Younger workers do not go uncompensated for the lower value of their pension benefits. Labor contracts typically include fringe benefits of disproportionate value to younger workers, for example, maternity benefits. These current consumption benefits may compensate younger workers for the reduced present value of their pension benefits. Id. 
fund to decline-contrary to the interests of older employees and especially of retirees.

The simple truth is that any particular use of pension plan assets may have different consequences for different classes of employees. The conflicts that are bound to arise between these classes greatly complicate the application of the exclusive benefit rule. The exclusive beneflt rule requires a duty of loyalty from the trustee, but when conflicts develop, the rule provides no guidance as to how to balance the competing interests. The trust law duty of impartiality, which requires the trustee to treat divergent interests in an impartial manner, ${ }^{61}$ fits logically into the structure of pension trust law. We suggest that the duty of impartiality should be imported into pension law, and we discuss below how it could be applied in two settings where conflicts are most severe: takeover battles and social investing decisions.

\section{Shareholders versus employees.}

We have previously explained that in a defined benefit plan, investment risk incides on the employer or other plan sponsor. ${ }^{62}$ Employees are promised pension benefits that are not tied directly to the investment performance of the pension fund. Thus, the risk of fund performance is borne mainly by the firm's stockholders. This creates a potential for conflict very similar to the well known conflict between bondholders and stockholders. As residual claimants, stockholders typically prefer a riskier investment policy than bondholders, since the bondholders share risk in the event the investment strategy results in bankruptcy but do not share in the upside if it turns out well.

Shareholders face something of this same incentive with respect to the defined benefit pension plan. Even though the pension promise to the employees does not vary with the investment performance of the pension fund, the losses from poor investment performance will be shared by employees and the PBGC in the event of severe underfunding or plan defalcation. Thus, shareholders will prefer a riskier investment strategy than employees. Shareholders reap the benefits if risky investing succeeds, while the employees and the PBGC must shoulder some of the loses if the investments fare badly.

Another bondholder-stockholder type conflict that finds an

61 Restatement $\$ \S 183,232$ (reproduced in note 193).

${ }^{62}$ See text at notes $37-39$. 
echo in the defined benefit plan concerns distributions from the firm. Just as stockholders have incentives to withdraw assets from the firm to themselves in the form of dividends or other distributions, they have an incentive to underfund the defined benefit plan or to withdraw assets from it. We discuss the related problem of asset reversions in more detail below.

\section{The Protective Policy}

Pension plans are basically savings plans. The purpose is to facilitate saving for retirement. The rationale for making pension plans tax favored is to induce higher levels of retirement saving than would occur without the tax concessions. Accordingly, from the perspective of tax expenditure theory, it has become commonplace to view the resulting revenue loss as a tax subsidy. ${ }^{63}$ We recur to the point previously emphasized, that the private pension system is voluntary. Whereas the employer is required to offer Social Security coverage, there is no requirement that the employer offer a private pension plan. Since compliance with the regulatory and fiduciary structure of ERISA and of the Internal Revenue Code is costly, one way to understand the calculus that induces employers to sponsor pension plans is (1) that the tax benefits outweigh the costs of compliance, and (2) that employees will perceive and value these tax benefits over the benefits of the forgone cash compensation. Employers have no interest in foisting off pension plans on a workforce that does not want them. Thus, the patterns of pension coverage vary greatly across industries and firms, and pension coverage correlates strongly with the tax brackets of the workforce. ${ }^{64}$

Despite the strongly voluntary or consensual basis of the private pension system, various features of pension regulation are designed to interfere with individual autonomy in pension saving. For example, the anti-discrimination norm - the bedrock principle of pension taxation-conditions access to tax advantaged pension saving for a firm's better paid workers upon extensive participation

${ }_{63}$ Munnell, The Economics of Private Pensions at 50-59 (cited in note 52); Wolk, $70 \mathrm{Va}$ L Rev 419 (cited in note 25); Daniel I. Halperin, Retirement Security and Tax Equity: An Evaluation of ERISA, 17 BC Indust \& Comm L Rev 739 (1976). See also Michael J. Graetz, The Troubled Marriage of Retirement Security and Tax Policies, $135 \mathrm{U} \mathrm{Pa} \mathrm{L}$ Rev 851 (1987).

64 Ippolito tabulates data showing that for the year 1979, 10 percent of persons earning less than $\$ 5,000$ per year had private pension coverage, compared to 78 percent of those earning \$25,000 or more. Ippolito, Pensions, Economics and Public Policy at 24 (Table 2-3) (cited in note 39). 
of the firm's lower paid workers. The rationale is to create incentives for management to induce lower paid workers to engage in higher levels of pension saving than they would if allowed unfettered choice. ${ }^{\mathrm{BS}}$ Whether this strategy is very successful is open to question, ${ }^{\text {eb }}$ but it exemplifies the idea that some employees should be protected against their inclination to save too little for retirement.

Another manifestation of the protective policy in pension law is the effort to prevent the worker from consuming his pension savings before he retires. The Internal Revenue Code insists that pension plans be designed so that distribution in retirement will occur "over the lives of [the] employee and [his] designated beneficiary ...."67 This emphasis on postponing consumption until retirement is reinforced by a spendthrift provision, resembling the spendthrift restraint that can be created under conventional trust law. ERISA section 206(d)(l) says: "Each pension plan shall provide that benefits provided under the plan may not be assigned or alienated." 68 (The Internal Revenue Code contains an identical requirement for tax qualification. ${ }^{69}$ ) As in a spendthrift trust, ERISA's spendthrift provision has the effect of protecting the beneficiary's account from the just claims of his creditors. And, in ERISA trusts, as in spendthrift trust law, an exception is made in favor of domestic relations creditors (former spouses and dependent children), whose claims are enforced despite the spendthrift language. ${ }^{70}$

Although ERISA's spendthrift provision echoes the spendthrift trust, there are important differences. ERISA's spendthrift provision is mandatory, whereas under conventional trust law a spendthrift restraint is exceptional and must be expressly invoked

65 See Wolk, 70 Va L Rev at 429 et seq (cited in note 25).

${ }^{66}$ We are suspicious of the basic idea that an individual needs a tax bounty in order to make an appropriate tradeoff between current consumption on the one hand and deferred consumption in retirement on the other hand. But quite apart from that question of principle, there is considerable reason to think that the bounty does not achieve its goal. Munnell reckons that perhaps sixty-five cents of the pension savings dollar disappears in the form of dissaving from nonpension accounts. Munnell, The Economics of Private Pensions at 77 (cited in note 52). On the shortcomings in implementing the coverage goals of the antidiscrimination norm, see Wolk, $70 \mathrm{Va} \mathrm{L} \mathrm{Rev} \mathrm{at} 435$ et seq (cited in note 25).

${ }^{67}$ IRC \& 401(a)(9)(A)(ii), 26 USCS § 401(a)(9)(A)(ii).

8 ERISA § 206(d)(1), 29 USCS § 1056(d)(1).

6. IRC \& 401(a)(13)(A), 26 USCS § 401(a)(13)(A).

70 Compare Restatement $\S 157$ (a) (cited in note 17), with the current ERISA provision, $\S 206(d)(3)(A), 29$ USCS $\S 1056$ (d)(3)(A). (The exception for domestic relations creditors was not in the original Act. It was added by amendment in 1984.). 
by the settlor. ${ }^{71}$ On the other hand, ERISA tolerates greater departures from its spendthrift protection than is characteristic of a spendthrift trust. ERISA allows loans and lump sum distributions in circumstances that seem to undercut the protective policy. ${ }^{72}$

ERISA's spendthrift provision also collides with a basic principle of black letter trust law, that the settlor of a trust may not impose spendthrift protections against his creditors for his own advantage. ${ }^{73}$ In ERISA trusts there is an important sense in which the employee whom the spendthrift provision shields is the settlor of his own pension account, since even contributions that are nominally made by the employer derive in function from the employee's aggregate compensation. On the other hand, we have emphasized that the employer has settlor-like interests in the employee's pension saving; those interests may extend to the spendthrift provision. From the employer's standpoint, one of the advantages of pension saving is that it facilitates superannuation policy: ${ }^{74}$ The employee who has an assured retirement income stream is less likely to want to remain on the job beyond his productive years. With the stick of the mandatory retirement rules now severely circumscribed, the carrot in the pension pot is an ever more important tool in a firm's superannuation policy.

The proper scope of ERISA's protective policy for the most part lies well beyond the subject of the present article. We have mentioned these few basics because the protective policy has important implications for one of the recurrent themes of this article, the conflicts of interest that exist among different groups of employees. We shall show, for example, that both in the leading takeover case and in the leading social investing case, there were significant conflicts between active employees concerned to protect their jobs and senior employees or retirees who had no such interest. If the protective policy were pursued relentlessly, it might lead to the view that the preferences of active employees should be disregarded. Consider, for example, the defined contribution plan--in

${ }^{71}$ See Restatement $\S 152(1)$ (cited in note 17), providing that a spendthrift trust is valid if created "by the terms of [the] trust."

${ }^{72}$ ERISA $\S 408(\mathrm{~b})(1), 29$ USCS $\S 1108(\mathrm{~b})(1)$, allows loans to plan participants and beneficiaries. IRC $\S 402$ (e)(4)(A) permits lump sum distributions in various circumstances, including (when the plan so provides) termination of employment. Most lump sum distributions result in immediate consumption rather than savings for retirement. See Spend It or Save It?, 49 Social Secur Bull 15 (Sept 1986).

${ }^{73}$ Restatement $\$ 156$ (cited in note 17 ).

74 Everett T. Allen, Jr., Joseph J. Melone and Jerry S. Rosenbloom, Pension Planning: Pensions, Profit Sharing, and Other Deferred Compensation Plans 7-8 (Richard D. Irwin, 5th ed 1984). 
which, as we have explained before, investment risk always incides on the employee. The argument would be that if the protective policy forbids an active employee to resort to his pension account for current consumption, it should likewise prevent him from approving pension fund financial transactions that trade lower investment gains in return for current employment. Either way, the employee is obtaining current income at the price of a reduced retirement income stream. That argument is, however, overstated. Current employment supports not only current consumption, but also pension saving. The employee may gain little if his pension account is protected at the price of his job. If he cannot be quickly reemployed in a comparable position, the loss of the job will impair his future pension saving.

Another reason for limiting the scope of the protective policy is that, in the situations we shall be discussing, the employee does not ordinarily act alone, but as a member of a larger group, often with union representation. The spendthrift clause is premised on a distrust of the ability of the individual employee to make the tradeoff between current consumption and pension saving. Even if this distrust of the individual employee were justified (and we have our doubts), it should not be mechanically transposed to the better informed circumstances of collective action.

There is no ground for assuming that if fiduciaries and courts were to recognize the true contest of interests that exists in various issues of pension plan governance, the result would be to encourage foolish employees to fritter away their pension savings. A more likely result is that if fiduciaries and courts were directed to identify and weigh all the relevant interests, they would be better able to maximize the interests of all the parties. In a world of voluntary plan formation, if the contracting parties understood that the legal standards for evaluating plan decisionmaking had become more realistic and more reasonable, they would be more likely to form plans and to establish higher levels of pension saving.

In the remainder of this article, we examine a variety of issues that have arisen under ERISA in which the common thread, as we see it, has been the multiplicity of interests in pension and welfare benefit plans and the distortions that result when the exclusive benefit rule has the effect of concealing the relevant interests. 


\section{The Nonneutral Fiduciary}

The most visible problem with ERISA's exclusive benefit rule arises from section 408(c)(3), which allows the employer or other plan sponsor to have its own "officer, employee, agent, or other representative" serve as trustee or other fiduciary. ${ }^{75}$ Rather than insist upon an employee-chosen fiduciary, or upon a wholly independent fiduciary (chosen, for example, in the manner of an arbitrator), the statute leaves the plan sponsor to pick the fiduciary and, if the sponsor pleases, to do it from the ranks of management. Sponsors routinely exercise this authority. In single employer plans, higher officers of the firm frequently oversee plan investments while other managers handle various types of benefit determination. In the union dominated multiemployer plans, it is common for union officers to wear pension fiduciary hats.

This authorization for the use of nonneutral fiduciaries creates an obvious tension with the duty of loyalty that is enshrined in the exclusive benefit and prohibited transaction rules. As the lower court observed in Donovan $v$ Bierwirth, the most celebrated ERISA fiduciary case, "section 408(c)(3) expressly contemplates fiduciaries with dual loyalties," and this arrangement is "an unorthodox departure from the common law rule against dual loyalties ....."76

Dual loyalty does indeed appear to contrast markedly with the supposed duty of exclusive loyalty to the employees. But the tension disappears once it is recognized that in pension plans, unlike traditional trusts, employers and employees are both settlors and beneficiaries. Dual loyalty is simply a recognition of this basic point.

ERISA allows, but does not require, that the trustee or trustees of a single employer plan be representatives of the employer. Nothing in ERISA prevents the choice of a union representative or an independent third party as plan trustee. ERISA allows the parties in creating a pension trust to select whomever they think maximizes their joint welfare.

Suppose Congress had adopted the opposite rule; suppose,

75 ERISA $\S 408(c)(3), 29$ USCS $\S 1108(c)(3)$, provides that the prohibited transaction rules of ERISA $\S 406,29$ USCS $\S 1106$, shall not be construed to prohibit someone from "serving as a fiduciary in addition to being an officer, employee, agent, or other representative of a party in interest." ERISA $\S 3(14), 29$ USCS $\S 1002(14)$, defines "party in interest" to include employers and other plan sponsors.

${ }^{78}$ Donovan v Bierwirth, 538 F Supp 463, 468 (E D NY 1981) (citation omitted), aff'd as modified, $680 \mathrm{~F} 2 \mathrm{~d} 263$ (2d Cir 1982), discussed in text at notes 121-26. 
that is, that the sponsor had been forbidden from using its own people as plan fiduciaries. Concentrate on the defined benefit plan, which is the overwhelmingly prevalent form of welfare benefit plan as well as the predominant form of pension plan. Bear in mind that plan fiduciaries are routinely responsible for making two major sorts of decisions: how to invest plan assets, and how to deal with benefit claims. Under a defined benefit plan, financial risk incides on the employer. ${ }^{77}$ If plan assets are invested poorly, the employer is liable for the shortfall. Likewise if the plan is lavish in paying unfounded benefit claims, the employer bears the cost.

Accordingly, the cost of a firm's pension and benefit plans comes more or less directly off the firm's bottom line. The effect of forbidding the firm to conduct investments and determine benefits-functions for which the firm is liable-would be to lower the rate of plan formation. The firm would be alarmed about assuming financial liabilities without effective controls. Employers tend not to write blank checks.

This discussion of the rationale for permitting the nonneutral fiduciary illustrates a larger point that is one of the major themes of this article. There is an important distinction between the operation of a legal rule ex ante and ex post. Viewed from the ex post perspective, a rule allowing the employer's representative to make decisions on behalf of the trust appears to be inconsistent with the exclusive benefit rule. Ex ante, however, this inconsistency abates when we come to understand that a contrary rule might lower the rate of plan formation. Employees would not be well served by a legal rule that decreases the incentive to form plans in the first instance.

The failure to recognize this fundamental distinction between the effect of a rule ex ante and ex post has led to doctrinal confusion in the few cases that have discussed section 408(c)(3). In Donovan $v$ Bierwirth, the important takeover case that we discuss in detail below, ${ }^{78}$ Judge Friendly attempted to reconcile the exclusive benefit rule with the nonneutral fiduciary of section 408(c)(3) by downplaying the conflict. Nonneutral trustees must make "their decisions ... with an eye single to the interests of the participants and beneficiaries;" nevertheless, they "do not violate their duties as trustees by taking action ... to promote the interests of participants and beneficiaries simply because [the action] incidentally

${ }^{18}$ See text at notes 121-26. 
benefits the corporation ....."79

The device of characterizing the benefit to the employer as "incidental" misses the point by confusing the ex ante and ex post perspectives. The relevant question is not whether the trustee's conduct creates only an "incidental" benefit for the employer ex post, a difficult and ultimately futile inquiry. Rather, the relevant question is whether the trustee's conduct is consistent with the understanding that the employees and the employer would have reached had they bargained over the issue ex ante. Any other approach will lower the rate of plan formation to the detriment of employees and employers alike.

The confusion between the ex ante and ex post perspectives is also evident in the requirement that trustees must act with an "eye single to the interests of the participants and beneficiaries." The difficulty with this requirement is that it begs the question of who the beneficiaries are. If the employer were also understood to be a beneficiary from the ex ante perspective, the dual loyalty problem would be greatly reduced.

ERISA creates an apparent tension between its exclusive benefit rule and its authorization of nonneutral fiduciaries, yet the statute does not mesh the two contrasting principles nor otherwise guide the courts on how to balance them. That so distinguished a jurist as Judge Friendly could find no better rationale for self-interested behavior by nonneutral fiduciaries than to call it incidental is a measure of the power of the exclusive benefit rule to mislead courts about the reality of pension and benefit plans. If the court tries to adhere to the notion that a plan is for the exclusive benefit of the employees, then when confronted with section 408(c)(3), which is apparently based upon the counterprinciple, the tendency is to subordinate it or wish it away, in this instance by calling it incidental. The better approach, as we have emphasized, would be to apply the exclusive benefit rule in a fashion that recognizes that for some purposes the employer is also a beneficiary of the pension plan.

\section{Plan Administration}

Plan administrators are constantly called upon to decide whether benefit claims fall within plan terms. Most such matters

79680 F2d at 271. See also Foltz v U.S. News \& World Report, Inc., 608 F Supp 1332, 1344 (D DC 1985), aff'd in part, vacated in part (on other grounds), 760 F2d 1300 (DC Cir 1985), on remand 613 F Supp 634 (D DC 1985). 
resolve themselves easily, but at the margin there can be doubt about how particular plan terms apply to particular circumstances. Judicial review of plan benefit denials has produced an enormous body of case law ${ }^{80}$ How blind must a worker be in order to qualify under a disability plan ${ }^{81}$ When a worker leaves the firm's employment, is he entitled to immediate distribution of his profit sharing plan account, or must he wait until normal retirement age ${ }^{82}$ When a corporation sells a division to another firm, and the buying firm continues to employ the division's workers, does the transfer entitle the workers to benefits under the selling corporation's severance pay plan? ${ }^{83}$ When the employer first reduces wages and later dismisses workers, are the workers' severance plan benefits calculated at the reduced or the unreduced rate? ${ }^{84}$

Dozens of such issues are being litigated under ERISA. Section 503 of ERISA obliges every plan to have a written claims procedure, including an internal review process conducted "by the appropriate named fiduciary ...." participants and beneficiaries to sue to recover or to enforce rights under a plan. ${ }^{86}$ Thus, ERISA invites this litigation, yet the statute gives the courts no express guidance about what substantive standard to apply in reviewing the decisions of plan fiduciaries. Because ERISA preempts state law on matters relating to pension and employee benefit plans, ${ }^{87}$ yet is silent about the standard of review to apply in these cases, courts have had to construct the standard as a matter of federal common law.

Here as elsewhere in the development of ERISA jurisprudence, two older bodies of law have proven influential: the law of private trusts, in which the courts have emphasized the importance

${ }^{80}$ Dozens of reported cases are collected in Charles B. Wolf and John J. Jacobsen, ERISA Claims \& Litigation 79-81 (Federal Publications, 1988).

${ }^{81}$ See, for example, Pokratz v Jones Dairy Farm, 771 F2d 206 (7th Cir 1985); LeFebre $v$ Westinghouse Electric Corp., 747 F2d 197 (4th Cir 1984).

${ }^{82}$ Severs v Allied Construction Services, 795 F2d 649 (8th Cir 1986); Morse v Stanley, 732 F2d 1139 (2d Cir 1984).

${ }^{83}$ Compare Harris v Pullman Standard, Inc., 809 F2d 1495 (11th Cir 1987); and Blau v Del Monte Corp., 748 F2d 1348 (9th Cir 1984); with Simmons v Diamond Shamrock Chemicals Co., 658 F Supp 1053 (E D Mo 1987), affd 844 F2d 517 (8th Cir 1988); and Jung $v$ FMC Corp., 755 F2d 708 (9th Cir 1985).

84 Ahne v Allis-Chalmers Corp., 640 F Supp 912 (E D Wis 1986).

8s ERISA § 503(2), 29 USCS § 1133(2).

${ }_{86}$ "A civil action may be brought . . . by a participant or beneficiary . . . to recover benefits due to him under the terms of his plan ...." ERISA $\S 502(\mathrm{a})(1)(\mathrm{B}), 29$ USCS $\S$ $1132(a)(1)(B)$.

${ }^{87}$ See discussion in text at notes 4-5. 
of allowing the trustees broad latitude in administration; ${ }^{88}$ and the law generated by prior federal regulation of pension trusts under the Taft-Hartley Act. For ERISA, the federal courts transposed the standard of review they had developed in similar litigation challenging the decisions of Taft-Hartley multiemployer plan trustees. $^{89}$

The Taft-Hartley standard of review is known as the "arbitrary-and-capricious" doctrine. Trustees "may be reversed only where [their decisions] are arbitrary, capricious or made in bad faith, not supported by substantial evidence, or erroneous on a question of law." We have seen that Taft-Hartley section 302(c)(5) imposes an exclusive benefit rule. ${ }^{91}$ The arbitrary-and-capricious doctrine rests on that rule. The reasoning is that when plan fiduciaries deny benefits unreasonably, they are not acting "for the sole and exclusive benefit of the employees" as Taft-Hartley requires. When the federal courts were faced with challenges to fiduciary decision making under ERISA, it was a simple step to adopt this rubric as the basis for review under ERISA's nearly identical exclusive benefit rule. ${ }^{92}$

The arbitrary-and-capricious standard for the review of plan decision making allows a court to defer to the presumed expertise of the decision maker, much as in administrative law. "Here, as in other contexts, the standard exists to ensure that administrative responsibility rests with those whose experience is daily and continual, not with judges whose exposure is episodic and occasional." ${ }^{\text {93 }}$ In Dennard $v$ Richards Group, Inc., an oft-cited ERISA case, Judge Brown observed that the arbitrary-and-capricious standard has been "traditionally used for review of trusts" and "prevents excessive judicial intervention in trust operations."

${ }^{88}$ "Where discretion is conferred upon the trustee..., its exercise is not subject to control by the court, except to prevent an abuse by the trustee of his discretion." Restatement $\S 187$ (cited in note 17). The broad discretion of the trustee in plan administration is circumscribed by rigid rules of fiduciary duty that allow no discretion in certain circumstances. See discussion of fiduciary rules at notes 45-50.

${ }^{89}$ See Comment, The Arbitrary and Capricious Standard Under ERISA: Its Origins and Application, 23 Duquesne L Rev 1033, 1035-41 (1985).

${ }^{90}$ Rehmar v Smith, 555 F2d 1362, 1371 (9th Cir 1976).

91 See text at notes 24-27.

92 "ERISA essentially codified the strict fiduciary standards that a $\$ 302(c)(5)$ trustee must meet." NLRB v Amax Coal Co., 453 US 322, 332 (1981). "The actions of trustees are subject to the same standard of review under the ERISA's fiduciary provisions as they are under [Taft-Hartley]." Elser v I.A.M. National Pension Fund, 684 F2d 648, 654 (9th Cir 1982).

${ }^{93}$ Berry o Ciba-Geigy Corp., 761 F2d 1003, 1006 (4th Cir 1985).

${ }^{94} 681$ F2d 306, 313 (5th Cir 1982). 
Judge Brown's formulation assumes two propositions: first, that a deferential standard of review is appropriate to ordinary private trusts; and second, that pension and employee benefit trusts are comparable to ordinary private trusts and entitled to equivalent judicial deference. We have previously explained why the strict duty of loyalty in conventional trust law justifies the courts in deferring broadly to trustee decision making. ${ }^{95}$ The trustee who is precluded from self-interested behavior can be allowed substantial latitude in administering the trust, thereby sparing the enforcement costs of a closer standard of review. We question, however, whether that basis for deference should carry over from the private gratuitous trust to the realm of pension and employee benefit trusts.

ERISA trustees are not the wholly disinterested fiduciaries that the common law of trusts presupposed when crafting its broadly deferential standard of review. ${ }^{96}$ We observed above how section 408(c)(3), which authorizes the sponsor to use its own "officer, employee, or other representative" as plan fiduciary, undercuts the traditional duty of loyalty. ${ }^{97}$ Welfare benefit plans and defined benefit pension plans affect the employer's bottom line more or less directly. When a benefit claim is denied, the employer's liability is reduced. Yet ERISA invites management personnel to make these decisions. In this setting, the premise that justifies the deferential arbitrary-and-capricious standard of review is questionable.

But the existence of nonneutral fiduciaries does not necessarily compel rejection of the arbitrary-and-capricious standard of review. First, as discussed above, the parties who establish a pension trust always have the option of selecting a neutral fiduciary but typically do not choose to do so. Even in the setting of the single employer plan with union represented employees, there has been scant effort to displace management dominated fiduciaries. This suggests that the levels of abuse are very low. Especially under health care plans, millions of benefit decisions are made every week. The fraction that remains contentious is minuscule. In the vast preponderance of cases, plan terms apply straightfor-

95 See text at notes $45-50$.

9s We speak in the text of single employer plans. As regards multiemployer plans, the Supreme Court has tried to orient management appointed trustees away from serving management interests, see NLRB v Amax Coal Co., 453 US 322 (1981). However, the more endemic conflict of interest in these union dominated plans arises from the side of the union selected trustees. See text following note 113.

97 See section IV. 
wardly and the fiduciary's discretion is unimportant.

Second, most plan decision making occurs in the setting of long term or repeat player relations. Management dominated fiduciaries typically have strong incentives not to acquire a reputation for sharp practice that would harm morale and cause employees to assign lower value to plan benefits. Third, in the situation of the single employer plan in a unionized workforce, the amount of mischief that results from the existence of nonneutral fiduciaries is minimized by the ability of the union to monitor fiduciary decision making and to react against abuse. Finally, abrogating the arbitrary-and-capricious standard is a step that is far from costless. The alternative to routine deference is routine judicial displacement of plan decision making in contested cases. While judges may be more disinterested than nonneutral fiduciaries, they are also less informed and have weaker incentives to maximize the value of the firm to the benefit of employers and employees alike. Under these circumstances, there is no presumption that judicial decision making would represent an improvement over the deferential arbitrary-and-capricious standard.

Sometimes, however, the safeguards that protect employees' interests in the absence of strict judicial review break down. Union monitoring and the employer's reputational interest are not likely to be effective when the long term relationship between the firm and the union is dissolving, as in plant closings or in corporate reorganizations. In these cases, the gains from self-interested action by nonneutral fiduciaries may outweigh the usual inhibiting future costs. $^{98}$

It is for this reason, we suspect, that the contested plan administration cases so often arise when the incentives of the long term relationship are attenuated. Much of the recent litigation in which the courts have expressed uneasiness about the arbitraryand-capricious doctrine has arisen in a recurrent fact pattern: An employer who has a severance pay plan for terminated employees sells a division to another firm. The issue is whether the employees are severed, since they are removed from the employer's workforce, even though they have employment continuity with the successor firm. One factor that sets these cases apart from routine plan administration disputes is that, since the employer is shedding the aggrieved employees (and sometimes their union as well), the long term relational incentives no longer pertain.

${ }^{83}$ See Fischel and Bradley, 71 Cornell L Rev 261 (cited in note 48), for extensive discussion of this problem. 
Given the complexity of the competing considerations and the diverse fact patterns in plan administration cases, it is not surprising that courts have reached inconsistent results. Until lately, the case law has mostly validated fiduciary decision making, by applying the deferential arbitrary-and-capricious standard. ${ }^{.9}$ On the other hand, some courts have been reluctant to apply the arbitrary-and-capricious standard reflexively. These courts have developed various presumptions that overcome the arbitrary-and-capricious standard and impose a burden on the fiduciary to justify his decision. For example, when the fiduciary adheres to a rule that excludes a disproportionate number of participants from receiving benefits, these courts require the fiduciary to justify the rule; and similar burden-shifting presumptions are applied against plan rules that work retroactively or that favor junior over senior workers. ${ }^{100}$ The decision whether or not the facts justify invoking one of these presumptions leaves the courts with considerable discretion and has produced a case law that is sometimes hard to reconcile. ${ }^{101}$ Still other courts appear to have completely abrogated the arbitrary-and-capricious standard in some cases. ${ }^{102}$

This last group of cases, as our analysis suggests, frequently involves situations in which conventional safeguards such as union monitoring and the employer's reputational incentives are not adequate to protect the interests of employees. In these cases, the courts have been properly sensitive to the possibility of self-interested action by nonneutral fiduciaries to the detriment of the employees.

Consider, for example, the strike bound firm whose managers

"See, for example, Severs v Allied Construction Services, Inc., 795 F2d 649, 650 (8th Cir 1986). Severs sought lump sum distribution of his profit-sharing account when he quit:

The committee which administers the Plan informed Severs that an accelerated distribution would be granted if Severs would execute a limited covenant not to compete with Allied for two years. However, Severs refused to do so. Rather, he proceeded to work in direct competition. . . . Based upon Severs' refusal to sign tbe noncompetition covenant, the committee denied the request. . . .

The court sustained the committee's decision under the arbitrary-and-capricious standard. See also Fielding $v$ International Harvester Co., 815 F2d 1254, 1256 (9th Cir 1987) (while agreeing that a conflict of interest existed, the court stated that it will continue to apply the deferential arbitrary-and-capricious test).

${ }_{100}$ Ninth Circuit law on these matters is summarized in Harm v Bay Area Pipe Trades Pension Plan Trust Fund, 701 F2d 1301, 1305 (9th Cir 1983).

${ }^{101}$ For example, compare Harm, 701 F2d 1301, with Shishido o SIU-Pacific DistrictPMA Pension Plan, 587 F Supp 112 (N D Cal 1983).

${ }_{102}$ See especially, Bruch v Firestone Tire \& Rubber Co., 828 F2d 134 (3d Cir 1987), cert granted as Firestone Tire \& Rubber Co. $v$ Bruch, $108 \mathrm{~S} \mathrm{Ct} 1288$ (1988), discussed in text at notes 109-114. 
were plan fiduciaries in Dockray v Phelps Dodge Corp. ${ }^{103}$ The pension plan administrator was the corporation's director of employee benefits. The plaintiff joined a strike against the firm and the firm replaced him. When the plaintiff filed for benefits under the plan's early retirement scheme, the administrator ruled that the plaintiff did not qualify because he had not been laid off but had quit, although another company official had previously relied upon the opposite rationale for excluding the plaintiff from the firm's health and insurance plans. The court pointed to "countervailing tugs of divided loyalty" pulling at the plan administrator, ${ }^{104}$ and concluded that it would be "unrealistic to grant the same substantial deference to the [benefit denial made] . . . by an administrator who is also a senior member of [the firm's] management as we would to the decision of a wholly independent fund trustee in similar circumstances." 105

In Jung $v$ FMC Corp. ${ }^{106}$ one of the cases involving the question of whether the sale of a division entitles the division's employees to severance pay under the plan of the selling corporation, the Ninth Circuit ruled that the fiduciary's conflict of interest justified a more searching standard of review. "Where, as here, the employer's denial of benefits to a class avoids a very substantial outlay, the reviewing court should consider that fact in applying the arbitrary and capricious standard of review. Less deference should be given to the trustee's decision."107 In another of these severance plan cases, a district judge explained: "Because private trustees may be less well insulated from private pressures [than are government officials] ...., I have given even more scrutiny to the evidence."108

Similarly, in Bruch v Firestone Tire \& Rubber Co., the Third Circuit effectively abrogated the arbitrary-and-capricious standard in comparable circumstances. ${ }^{109}$ The employees who claimed severance benefits under the Firestone plan were terminated when Firestone sold their division, but the successor employer continued their employment. The trustee of the Firestone plan, a representative of Firestone, rejected the claims. Judge Becker emphasized

\footnotetext{
103801 F2d 1149 (9th Cir 1986).

104 Id at 1152 .

105 Id at 1153.

108755 F2d 708 (9th Cir 1985).

107 Id at 711-12.

${ }^{108}$ Aquin v Bendix Corp., 637 F Supp 657, 668 (E D Mich 1986).

${ }^{109} 828$ F2d 134. The Third Circuit's position was foreshadowed in Struble $v$ New Jersey Brewery Employees' Welfare Trust Fund, 732 F2d 325 (3d Cir 1984).
} 
that "under ERISA courts must be cognizant of the features that distinguish the ERISA arrangements from the paradigmatic common law situation,"110 in particular that in this unfunded severance pay plan, "every dollar saved by the administrator on behalf of his employer is a dollar in Firestone's pocket."111 Judge Becker gave two main reasons for declining to defer to the presumed expertise of the plan decision maker. First, a benefit denial case does not ordinarily "turn on information or experience which expertise as a claims administrator is likely to produce." Rather, the case "is likely to turn on a question of law or of contract interpretation. Courts have no reason to defer to private parties to obtain answers to these kinds of questions." Furthermore, the "significant danger that the plan administrator will not be impartial . . . offsets any remaining benefit which the administrators' expertise might be thought to produce."112

In Jung, Dockray, and Bruch, therefore, courts effectively rejected the arbitrary-and-capricious standard in situations in which the safeguards that tend to align the interests of employers and employees were absent. In these situations, a pension or benefit plan may be well advised to remit benefit claims to truly neutral decision makers. ${ }^{113}$ Only in this manner can there be any assurance that a court will consistently apply the deferential standard of review epitomized in the arbitrary-and-capricious doctrine.

In the Bruch case Judge Becker endorsed the arbitrary-andcapricious standard for Taft-Hartley plans while disdaining it for ERISA plans. He reasoned that the Taft-Hartley Act, by insisting on labor-management parity in the trusteeship boards, "assure[s] that the plan administrator will be neutral."114 We have reservations about how neutral the boards of Taft-Hartley plans in fact are; there is a long tradition of union domination in many multiemployer plans, despite the nominally equal number of management and union trustees. In the worst case, a management selected trustee for a multiemployer plan sponsored by a mobster dominated union risks labor trouble or worse if he defies the wishes of

110 Bruch, 828 F2d at 143.

111 Id at 144.

112 Id (footnotes omitted).

11 Notice that in other circumstances in which a plan fiduciary's conflict of interest is thought to be acute, such as in contested takeover cases, the courts have on occasion insisted on appointing an impartial substitute to replace the regular fiduciary. See, for example, Danaher Corp. v Chicago Pneumatic Tool Co., 635 F Supp 246, 250 (S D NY 1986) (discussing the point and citing earlier cases).

$11628 \mathrm{~F} 2 \mathrm{~d}$ at 144. 
the union. Such trouble is directed solely against him or his firm (not against his competitors in the industry), whereas he suffers no competitive disadvantage if he lets the union selected trustees call the shots. It is not surprising, therefore, that the Jimmy Hoffas of the union world tend to get what they want in multiemployer plan administration despite the nominally neutral board structure. Nevertheless, the underlying insight in Judge Becker's opinion is surely correct and worth emphasis: A pension or benefit plan that does remit benefit denial cases to truly neutral decision makers should be rewarded with the deferential standard of review epitomized in the arbitrary-and-capricious doctrine.

Another recurrent difficulty faced by courts in deciding whether to apply the deferential arbitrary-and-capricious standard is whether the existence of a conflict of interest between the trustee and employees should be determined from an ex ante or an ex post perspective. Consider the case of a key employee of a firm who quits to work for a competitor and then demands accelerated lump sum distribution of his vested benefits. From an ex post perspective, it appears that a trustee who is a representative of management has a conflict of interest. From an ex ante perspective, however, the existence of a conflict of interest is far less obvious. Since rules that discourage key employees from working for competitors may maximize the value of the firm to the benefit of all claimants including employees, denial of accelerated benefits to employees who attempt to follow this course may be fully compatible with the interests of employees as a class. On the other hand, the absence of an express contractual provision establishing how claims for accelerated benefits should be handled when a key employee leaves to join a competitor makes proper resolution of the issue uncertain.

Morse $v$ Stanley ${ }^{115}$ illustrates this dilemma. Three key employees of a firm quit and went to work for a competitor. Each of the three asked for accelerated lump sum distribution of his vested benefits under the firm's profit sharing plan, rather than leave the proceeds invested in the plan until normal retirement age. The terms of the plan left to the trustees' discretion matters touching the timing of distributions. The trustees, who were senior managers of the firm, and who had granted seventy-nine consecutive previous requests for accelerated distribution to departing employees, refused the request of the three plaintiffs. The trustees declared 
that they were adhering to a previously undisclosed policy of not granting "accelerated distributions to employees who went to work for competitors in cases where the amount of the vested benefits" was as large as in the present instances. ${ }^{116}$

The Second Circuit sustained the trustees' determination against the employees' contention that it violated the exclusive benefit rule. The court reasoned that "[s]ince the Plan is a profit sharing plan funded ... entirely by employer contributions, the amount of funding depends upon the amount of profits generated by the business."117 Accordingly, the trustees could impose a rule designed to discourage departures and competition without breaching their duty. The court relied on Judge Friendly's reasoning in Donovan v Bierwirth, that "[o]fficers of a corporation often are trustees of its benefit plan. It is no violation of a trustee's fiduciary duties to take a course of action which reasonably best promotes the interest of plan participants simply because it incidentally also benefits the corporation." 118 Thus, the conduct of the firm's managers was held to be consistent with the exclusive benefit rule.

The court's reliance on the premise that the firm received only an "incidental" benefit as a result of the trustees' decision is subject to the same criticism that we made of Judge Friendly's reliance on that ploy in the Bierwirth case. ${ }^{118} \mathrm{~A}$ more plausible basis for the Second Circuit's result, however, would be to reason from an ex ante perspective that no conflict of interest existed. ${ }^{120} \mathrm{Ex}$ ante, both employer and employees shared an interest in the firm's profitability: the bigger the pie, the more to go around. Thus, employer and employees shared an interest in setting up the pension plan in a way that maximized the value of the firm. The rule in Morse $v$ Stanley - that trustees are entitled to distinguish between the claims of departing key employees who go to work for a competitor and the claims of departing employees who do not-is con-

116 Id at 1142 .

117 Id at 1146.

118 Id, citing Donovan v Bierwirth, 680 F2d 263, also discussed in text at notes $76-78$ and 121-26.

11 See text following note 79.

120 Even from an ex post perspective, there is no conflict between the trustees and the interests of employees as a class. Rather, the conflict is between those employees who quit and those employees who remain. The court alluded to this notion when it explained that "since an exodus of key ... employees plainly reduces the growth and fiscal strength of the Plan, the Trustees' decision to deny accelerated benefits to the [departing] employees here could scarcely be viewed as a breach of their duty to administer the Plan in the sole interest of all its participants." Morse, 732 F2d at 1146. 
sistent with this shared goal of value maximization since departures by the former group are hikely to have a greater adverse impact on the value of the firm.

While we endorse reliance on the ex ante perspective, it is hardly clear how Morse would have been decided had the ex ante perspective been applied. The issue is the familiar one in contract interpretation of the proper resolution of a dispute when the contract itself is silent. While the trustees' decision to deny accelerated benefits to the departing key employees can be defended as discussed above, it also can be criticized. Not only was the contract silent on the issue, but previous requests for accelerated benefits had apparently been granted routinely, albeit in different circumstances. Nor had the trustees articulated and communicated the supposed rationale for their decision in advance. These facts may suggest a course of dealing inconsistent with the trustees' decision. On the other hand, Morse is not a case in which the interests of employees were devoid of safeguard. The employer had an incentive to maintain a reputation for fair dealing among the remaining employees.

\section{TAKeOVER Bids}

\section{A. Use of Plan Assets as a Defensive Tactic}

Nowhere is the conflict among classes of plan beneficiaries more prominent than in situations involving takeover bids. Consider the facts in the leading case, Donovan $v$ Bierwirth. ${ }^{121}$ In September 1981, LTV Corporation made a tender offer for 70 percent of the outstanding common stock and convertible securities of the Grumman Corporation at $\$ 45$ per share, substantially higher than Grumman's pre-offer price in the mid $\$ 20$ range. At the time of the offer, the Grumman pension plan, a defined benefit plan, owned 525,000 shares of Grumman common stock that it had acquired in the mid-1970's. The trustees of the plan, including John Bierwirth, its chairman, were also senior managers of Grumman.

Bierwirth and Grumman's other directors took three main steps to oppose LTV's offer. First, in their capacity as corporate officers they filed an antitrust suit against LTV. Second, Bierwirth and the other trustees of the plan resolved not to tender the plan's shares to LTV, but instead to vote the shares against the merger. Third, they caused the plan to purchase an additional $1,158,000$ 
Grumman shares at an average price of $\$ 38.27$ per share, a price inflated by the public announcement of LTV's bid.

Grumman's defensive strategy succeeded. LTV's offer was defeated and, as a consequence, Grumman's stock price plummeted to the pre-offer level. The Secretary of Labor then sued the trustees, claiming that their actions violated the exclusive benefit rule under ERISA. The district court held that the Secretary had demonstrated a likelihood of success on his claim that the trustees had acted imprudently. The Second Circuit affirmed, in the opinion by Judge Friendly that we have previously mentioned. ${ }^{\mathbf{1 2 2}}$

The Second Circuit emphasized the serious conflict of interest arising from the trustees' dual role as senior managers of Grumman and trustees of the plan. Moreover, the court said, the trustees conducted an inadequate investigation and exaggerated the potential risks to the plan if LTV's offer were successful. The Second Circuit was especially critical of the trustees' decision, made after the LTV offer, to purchase the 1,158,000 additional Grumman shares at $\$ 10$ per share above the pre-offer price. The trustees were fully aware, the court observed, that the defeat of LTV's offer, which the trustees actions made more likely, would likely result in Grumman's stock price returning to its pre-offer level. This is exactly what occurred. Thus, the Second Circuit concluded that the trustees' conduct did not measure up to the "high standards" imposed by ERISA. ${ }^{23}$

Ultimately, the court viewed Bierwirth as an easy case. ERISA required the trustees to act with an "eye single"124 to the interests of the plan's participants and beneficiaries. The trustees' conduct in helping to defeat LTV's offer failed to meet this standard. Thus, the trustees breached their fiduciary duty to act solely in the interests of the plan's beneficiaries.

In reality, Bierwirth is a very hard case. Because the plan was a well funded defined benefit plan-the sort of plan in which almost all of the investment risk incides on the sponsor-Grumman's stockholders would bear the capital losses from adverse investment results. Pension plan participants, by contrast, would be relatively unaffected by investment losses. In their capacity as active employees, however, many of these same participants might have been harmed by the takeover if, for example, LTV would have closed Grumman plants or transferred or terminated

122 See text at note 78 .

${ }^{12 s} 680 \mathrm{~F} 2 \mathrm{~d}$ at 276.

124 Id at 271. 
Grumman employees. Thus, it was rational for workers to oppose the LTV offer and support plan purchases of Grumman stock to defeat the offer. This is precisely the position that most Grumman employees apparently took; ${ }^{125}$ recall that it was the Secretary of Labor, not the employees, who brought the Bierwirth lawsuit.

From the perspective of Grumman's stockholders, the situation was different. Not only did they bear the investment losses incurred by the plan, ${ }^{126}$ but they would have received a substantial premium for their shares had LTV been able to complete its offer.

The irony of the Bierwirth case should now be clear. The Secretary of Labor sued to redress an injury allegedly suffered by the participants and beneficiaries of the plan. Most of them, however, thought that they benefited from the defeat of LTV's offer and supported the trustees' actions. And in any event, because the plan in question was a well funded defined benefit plan, the investment risk was borne by the employer, not by the employees or the government insurer, the PBGC. The shareholders of the firm, by contrast, on whom the risk did incide, suffered the true injury, yet they went unrepresented in the case.

Bierwirth illustrates the problems created by literal application of the exclusive benefit rule when a takeover defense works to the advantage of one of the groups beneficially interested in the plan (employees) but harms another (shareholders). Under a different plan, the same underlying facts would have produced a different sort of conflict. If the Grumman pension plan had been a defined contribution plan instead of a defined benefit plan, the takeover defense would not have affected shareholders, since they bear no investment risk; but conflicts of interest between different subclasses of employees would have become noticeable. In a defined contribution plan that holds employer securities in individual employees' accounts, the capital gain on the sale of shares in a successful takeover would accrue to the employees' accounts. This result is simply an application of the general principle that invest-

125 Id at 265.

${ }^{128}$ The Second Circuit held in a subsequent decision that the Plan did not incur any losses because the Grumman securities purchased by the Plan were eventually sold for a higher price than that paid by the Plan. Donovan v Bierwirth, 754 F2d 1049 (2d Cir 1985). We think that decision is quite wrong. The sale occurred almost two years after the initial purchases. Grumman stock, like other defense stocks, rose in value during the early 1980 s as a result of the defense build up. This increase in the value of defense stocks should have been irrelevant in determining whether the plan incurred any losses at the time of the trustees' decision to oppose the offer. Instead, the Second Circuit allowed the trustees to appropriate by way of setoff the appreciation in trust assets. 
ment risk in a defined contribution plan incides on the participants rather than the sponsor. For younger employees, however, the concern over loss of employment may outweigh the benefit from receiving this capital gain. For older employees whose future income from prospective employment is smaller and whose prospective capital gain from the sale of shares is larger (since longer-service employees will have built up larger balances of plan shares), the capital gain may outweigh the risk of employment loss. And for retirees who cannot benefit from future employment with the firm, only the capital gain has value.

In one of the takeover cases that concerned a defined contribution plan holding shares of employer stock, Danaher Corp. $v$ Chicago Pneumatic Tool Co. ${ }^{127}$ the court addressed in dictum the trustee's contention that the shares should not be tendered because the participating employees preferred to defeat the offer. The district judge rejected this position and held that "the trustees must discharge their duties by evaluating the best interests of beneficiaries in the abstract as beneficiaries."128 The court recognized the tension between pension wealth and total wealth that the Second Circuit ignored in Bierwirth. Current participants would likely oppose the takeover bid, the court reasoned, because their jobs might be lost if a transfer of control occurred. "A participant," the court acknowledged, "would presumably rather see plan benefits slashed than lose completely the benefits of employment and independence."129 Yet, the court concluded that participants could not be trusted to make the decision whether or not to tender. This reasoning is a troubling variation of ERISA's protective policy. It is particularly difficult to understand why the trustee should not be able to consider the participants' interest in job security. After all, no job means no further plan benefits. If all plan participants were similarly situated, the conflict between plan benefits and current employment that concerned the court would not arise. In reality, plan participants rarely are similarly situated. ${ }^{130}$ But this is an ar-

${ }^{127} 635$ F Supp 246 (S D NY 1986). The case involved an employee stock ownership plan (ESOP). For discussion of the relationship between ESOPs and the exclusive benefit rule, see section IX.

${ }^{128} 635 \mathrm{~F}$ Supp at 250.

129 Id.

${ }^{130}$ The court worried that if voting rights were to be passed through to employees, "the vote of lower level employees may well be governed by fear of displeasing either present or future bosses. This is particularly a concern given the fact that none of Plan participants are unionized." Id. The court's concern is correct but the remedy lies elsewhere. The Department of Labor has insisted that when the plan is designed to pass the votes through to the employee/beneficiaries, precautions must be taken to prevent intimidation. See Labor De- 
gument for balancing the conflicting interests among the participants, not for denying the existence of conflicts. ${ }^{131}$

\section{B. The Plan as Acquiror}

The Bierwirth case raises the question of how to apply the exclusive benefit rule in takeover situations when the target company is using pension assets for a takeover defense. But the takeover situation can also pose a dilemma when the acquiring firm is using pension assets. In Leigh $v$ Engle ${ }^{132}$ an acquiring firm and its profit sharing plan simultaneously purchased shares of potential targets. As in Bierwirth, the trustees of the plan were also insiders of the flrm. Unlike Bierwirth, however, the plan was a defined contribution plan, in which investment risk incides on the employees, and the plan's investments in Leigh $v$ Engle turned out to be exceptionally profitable. Approximately 30 percent of the plan's assets were used to purchase shares in three potential targets. As a result of the takeover strategies pursued by the firm managers/plan trustees, these investments produced an annualized rate of return of about 70 percent on the plan assets deployed in the takeover schemes. Most of the gain came from two of the investments. The third investment, in Hickory Furniture Co., provided only a negligible return.

Notwithstanding the profitability of the investments, plan participants sued the trustees under ERISA. They claimed that when the trustees caused the plan to use plan assets to purchase shares of potential takeover targets, the trustees were motivated in part by the desire to benefit the firm rather than the plan, since the plan's investments were used to support the firm's acquisition strategy. The Seventh Circuit held that "the district court clearly erred when it concluded that plan assets were used exclusively in the interests of the beneficiaries." 133 In subsequent proceedings concerning the measure of damages, the Seventh Circuit upheld ${ }^{134}$ the district court's finding ${ }^{135}$ that the trustees were liable for $\$ 6704$, the amount by which the investment in Hickory Furniture underperformed a benchmark common stock fund. The trustees

partment Advisory Opinion on Fiduciary Responsibility in Connection with Attempted Corporate Takeovers, 11 Pension Rptr (BNA) 633 (1984). It seems likely that secret halloting will be required in such circumstances.

${ }^{131}$ See the discussion of recurrent conflicts in text at notes 57-72 and 135-50.

132727 F2d 113 (7th Cir 1984).

${ }^{133}$ Id at 124.

${ }^{134}$ Leigh v Engle, Nos 87-2548, 87-2609, and 87-2622 (7th Cir Sept 21, 1988).

${ }^{133}$ Leigh $v$ Engle, 669 F Supp 1390 (N D Ill 1987). 
were not ordered to disgorge the profits they had made on their own investment capital in the two successful ventures, on the ground that the use of plan funds had not been material to the trustees' gain. The trustees could have obtained capital from sources other than the plan, and the plan's share of the takeover ventures was not very large. The court thus rejected the plaintiffs' claim to capture all of the trustees' gains.

Our analysis suggests a different approach to Leigh $v$ Engle. As we have emphasized, employers and employees are both settlors and beneficiaries of pension plans. Thus, the use of pension assets for the joint benefit of both should not automatically be deemed to violate the exclusive benefit rule. The difficult issue in Leigh $v E n$ gle is not the exclusive benefit rule. Rather, the case should have focused on the issues of prudence and diversification. Because the use of trust assets to purchase shares of possible takeover targets is risky, and because workers in a profit sharing plan bear the losses if the strategy turns out poorly, it could be argued that use of plan assets for this purpose is imprudent. The fact that the strategy turned out well no more changes this conclusion than would winning the lottery prove that purchasing lottery tickets is prudent. Likewise, committing 30 percent of plan assets to investments in three small firms targeted for takeovers suggests underdiversification by the conventional standards of portfolio theory. On the other hand, the remaining 70 percent of plan assets was invested conservatively in fixed income securities, which decreased the riskiness of the portfolio. The fact that the acquiring firm had special information about the potential targets (i.e., it was interested in acquiring them) also lowered the riskiness and enhanced the prudence of the investments.

\section{Social INVESTING}

Over the past decade considerable controversy has swirled about the topic of social investing of pension and other trusteed funds. Social investing is commonly understood as an investment strategy that seeks to achieve some socially desirable goal (however defined) at the expense of a suboptimal economic return to the fund. This definition is unfortunate because it lumps together two quite distinguishable situations: (l) using plan assets for social purposes at the expense of all those persons who otherwise would benefit under the plan; and (2) using plan assets to benefit only a subgroup of those entitled to benefit under the plan.

The campaign to force pension funds to divest shares of firms doing business in South Africa typifies the first category. At a min- 
imum, such divestment is inconsistent with maximizing the return to the fund because divesting the shares of offending companies imposes additional transaction costs. ${ }^{136}$ (Depending on how many companies must be excluded from the fund's portfolio, some departure from optimal levels of diversification may result as well. ${ }^{137}$ ) In a defined contribution plan, the plan participants bear these additional costs; in a defined benefit plan, the costs incide upon the shareholders of the firm. Divestment thus poses a conflict between those who find investment in South Africa repugnant and either the plan participants or the shareholders who must pay the bill if the strategy is pursued.

Schemes to use plan assets to bail out failing employers or to create jobs for union members exemplify the second type of social investing: attempting to use plan assets to benefit some plan participants even if others are hurt. Indeed, the term "social investing" may be inappropriate in this second set of cases, for the rhetoric of social responsibility can obscure the self-interested motives behind these investment decisions. The much discussed case of Withers $v$ Teachers' Retirement System ${ }^{138}$ illustrates the genre. In the mid-1970s New York City was on the brink of bankruptcy. After exhausting credit from other sources, the City sought to sell new bonds to the pension trusts of several groups of municipal employees. As part of a program to prevent the City from going bankrupt, the trusts agreed to purchase bonds in the principal amount of $\$ 2.53$ billion. The Teachers' Retirement System (TRS), one of these trusts, committed $\$ 860$ million of its plan assets to the purchase. In the litigation that ensued, the parties conceded that the City could not have obtained the funds on comparable terms from any other lender.

Plaintiffs in the litigation were TRS retirees. Because ERISA does not apply to the affairs of state and local pension plans, the plaintiffs relied upon the common law of trusts. They challenged the trustees' decision to purchase the bonds as imprudent and con-

${ }^{138}$ The New Jersey Division of Investment, which oversees a portfolio with a current market value of $\$ 20$ billion, has estimated that it will incur $\$ 50$ million of transaction costs in selling the $\$ 4.2$ billion it has invested in South Africa related holdings (a transaction cost of approximately 1.2 percent of assets). See Trudy Ring, N.J. Plan Continues Divesting, 15 Pension \& Investment Age 3, 51 (April 6, 1987).

137 John H. Langbein \& Richard A. Posner, Social Investing and the Law of Trusts, 79 Mich L Rev 72, 77-89 (1980). See also, Ring, 15 Pension \& Investment Age at 3, 51 (cited in note 135), noting that the New Jersey Division of Investment's divestment policy has reduced the diversification of its portfolio and significantly limited its investment access to many major industries, including the chemical and automobile industries.

${ }^{138} 447$ F Supp 1248 (S D NY 1978), affd mem, 595 F2d 1210 (2d Cir 1979). 
trary to the duty of loyalty. The court, although conceding that under normal circumstances such a large purchase of highly speculative and unmarketable bonds would violate the trustees' fiduciary duties, rejected the plaintiffs' claims. The trustees, the court concluded, were entitled to take extraordinary action to stave off the City's bankruptcy.

In reaching this result, the court dealt explicitly with the plaintiffs' argument that the duty of loyalty (the common law analogue to ERISA's exclusive benefit rule) should have prevented the trustees from considering the welfare of New York City or even the preservation of employees' jobs. After reviewing the evidence, the court found that "neither the protection of the jobs of the City's teachers nor the general public welfare were factors which motivated the trustees in their investment decision."139 Rather, the court stated, extending "aid to the City was simply a means-the only means, in their assessment-to the legitimate end of preventing the exhaustion of the assets of the TRS in the interest of all of the beneficiaries."140

Thus, the court held that the trustees' action complied with the duty of loyalty. (Had the case arisen under ERISA, this result would have rested on the exclusive benefit rule.) The court was probably correct in its assessment that the trustees were not motivated by a concern for "the general public welfare." The court's conclusion that the investment was in the interest of all beneficiaries is, however, false. If the City had been unable to repay the loan, the more senior beneficiaries (such as the retirees who were the plaintiffs in Withers) who had the largest claims and whose claims were vested could have been harmed by the trustees' decision. The $\$ 860$ million that would have gone primarily, if not wholly, to them would have been lost.

More junior beneficiaries, by contrast, were benefited by the trustees' actions. The further they were from retirement, the more their ultimate retirement benefits depended upon the City remaining solvent and making contributions to the fund. ${ }^{141}$ Moreover, although the court dismissed the significance of this point, many teachers would have lost their jobs if the City went bankrupt.

139 Withers, 447 F Supp at 1256.

140 Id (emphasis added).

111 Notice the analogy to the situation that confronts different classes of creditors of a bankrupt firm. Senior creditors will typically prefer to liquidate the firm and get paid in full. Junior creditors, by contrast, who may receive nothing if the firm is liquidated, will typically prefer to reorganize. 
Thus, junior beneficiaries also benefited because the trustees' decision increased their prospects of retaining their jobs. In reality, therefore, the trustees' decision in Withers to provide aid to New York City involved a wealth transfer from older to younger beneficiaries. By incorrectly characterizing the trustees' decision as being in the interests of all beneficiaries, the court failed to appreciate the confiict between classes of beneficiaries and thus made the case seem easier than it actually was.

It is interesting to compare Withers with Blankenship $v$ Boyle, ${ }^{142}$ a pre-ERISA case that the court in Withers purported to distinguish. In Blankenship, the trustees of a United Mine Workers (UMW) pension and benefit fund authorized the purchase of large quantities of shares in certain electric utility companies. The purpose of these share purchases was to gain a position of influence with the utilities in order to pressure them into purchasing union mined coal. The fund benefited if the utilities purchased additional union coal, because the agreement between the UMW and the coal operators required the operators to pay a royalty to the fund for every ton of coal mined.

Notwithstanding this benefit to the fund from additional purchases of coal, the court found that the trustees' actions were primarily for the benefit of the UMW and the operators and not for the participants of the fund. The court held that the trustees' actions presented a "clear case of self-dealing ... and constituted a breach of trust."14s The court went on to enjoin "the trustees from operating the Fund in a manner designed in whole or in part to afford collateral advantages to the Union or the operators."144

What the court in Blankenship overlooked, however, was that most of the members of the union were also beneficiaries of the fund. Moreover, because of the royalty provision, the total receipts of the fund were a function of the amount of coal sold. Thus, the sale of coal benefited the union and the fund.

The court in Blankenship made the opposite mistake from that made in Withers. While the court in Withers pretended that no conflict between classes existed, the court in Blankenship exaggerated the extent to which conflicts existed. In reality, Blankenship and Withers involved a similar phenomenon-the use of plan assets meant to assure retirement income for the purpose of increasing current employment. To be sure, only some beneficiaries, 
particularly younger workers, may have benefited, but this was true in both cases. That some beneficiaries would benefit disproportionately thus does not provide a basis for distinguishing the cases.

A more plausible basis for distinguishing the cases, though not mentioned in either opinion, is the different degree of probability that these particular uses of plan assets would achieve their intended results. In Withers, the plan provided financial assistance to the City and thus increased the chances that bankruptcy would be avoided. In Blankenship, by contrast, it is unclear whether the stock purchases would have increased the demand for union mined coal. We assume that the reason the utilities had been unwilling to purchase union mined coal before the union inaugurated its stock purchase scheme was that union mined coal was more expensive than nonunion mined coal. If the union had acquired enough stock to achieve effective control, the union could have forced the utilities to purchase the more expensive coal. But this action would have depressed the value of the utilities' stock, including that held by the fund. Moreover, the other shareholders of the utilities could have attacked such a course of action, probably successfully, as a violation of the corporate law anti-self-dealing rules. Thus, the twin prospects of loss on the share investments and legal liability if the program had succeeded in its purposes may have made the scheme look very silly-indeed, silly enough to be imprudent.

Neither Withers nor Blankenship interpreted ERISA's exclusive benefit rule, since ERISA governed neither. The Department of Labor's ERISA oversight staff has consistently taken the position that the exclusive benefit rule forbids investment strategies that are designed to trade suboptimal financial returns for other goals. In 1979 the then-administrator of ERISA, Ian D. Lanoff, expressed the view that investing must be done "to protect the retirement income of the plan's participants," and that ERISA forbids "investment decisions based on other objectives, such as to promote the job security of a class of current or future participants."146 A principal reason most of the pressures for social investing in recent years have been directed at ERISA-exempt funds, such as state and local pension plans and university and other charitable endowments, is that within the universe of private pension funds that ERISA governs, the perception has been that the exclusive benefit rule forecloses the issue.

${ }^{145}$ Ian D. Lanoff, The Social Investment of Private Pension Plan Assets: May It Be Done Lawfully under ERISA?, 31 Labor L J 387, 389 (1980). 
Recently, however, in Donovan v Walton, ${ }^{146}$ a federal district court proved less sensitive to the language and the logic of ERISA's exclusive benefit rule in the social investing context. The case dealt with the effort of a multiemployer plan to invest pension plan assets for the purpose, in part, of creating jobs for union members. The trustees of the Operating Engineers Local 675 Pension Trust Fund decided to purchase and develop ninety-five acres of land in Broward County, Florida. Only firms whose employees were represented by the union were allowed to bid for development and construction contracts.

The Department of Labor sued, claiming among other things that the scheme was imprudent and contrary to the exclusive benefit rule. The district court rejected these claims. With respect to the exclusive benefit issue, the court stated: "To be sure, the Union derives some benefit from ... the Fund's requirement that contractors ... be party to collective bargaining agreements providing for pension fund participation."147 However, this was not inconsistent with the exclusive benefit rule because the court concluded that these benefits derived by the Union "are parallel to and inseparable from the benefits derived from the Fund and its participants." 148 Finally, "[e]ven without these benefits to the Fund," the court emphasized, the exclusive benefit rule "simply does not prohibit a party other than a plan's participants and beneficiaries from benefitting in some measure from a prudent transaction with the plan."149 The court appears to be saying that the union can benefit provided the plan and its beneficiaries also benefit. This rationale echoes Judge Friendly's "incidental benefit" stratagem in Donovan v Bierwirth..$^{150}$

A program of restricting bidders to those companies whose workers were represented by the union increases the costs and hence lowers the return to the fund. The companies who employ the presumably higher priced union labor benefit, as do their workers. Younger workers who otherwise would have never been hired or would have been laid off in the absence of the new jobs created benefit the most. Older workers protected by seniority rules benefit

14609 F Supp 1221 (S D Fla 1985), aff'd per curiam, sub nom Brock $v$ Walton, 794 F2d 586 (11th Cir 1986), rehearing en banc denied without opinion, 802 F2d 1399 (11th Cir 1986).

147 Id at 1245.

$148 \mathrm{Id}$

149 Id.

${ }^{180} 680$ F2d 263, discussed in text at notes 76-78. 
less. But the fund loses. ${ }^{151}$ Thus, the workers who are both members of the union and participants in the plan must balance their gains as union members against their losses as plan participants. Retirees, however, will have no gains as employees but only losses as plan participants. Thus, one important perspective on Walton is to understand it as a scheme by which active workers, particularly younger workers, and their employers appropriate wealth from retirees and perhaps from older workers as well.

\section{ASSET REVERSION}

Under a defined benefit plan the employer or other sponsor promises pension benefits whose amount and ultimate cost turn on a host of future variables-turnover in the workforce, inflation rates, salary levels, return on investment of pension fund assets, and many others. ${ }^{152}$ Contributions to the plan are based upon actuarial projections meant to take account of these factors, but the limits of human foresight cause discrepancies to arise between projection and result. Thus, the potential for underfunding or for overfunding inheres in the nature of a defined benefit plan.

When underfunding materializes, it is good actuarial practice (now reinforced by ERISA's funding requirements ${ }^{153}$ ) for the plan to revise its assumptions in order to increase the contribution levels or to take other measures to bring funding and benefits into alignment. When, on the other hand, a plan becomes overfunded, the sponsor can cause the disparity to abate simply by reducing or eliminating further contributions while new benefit entitlements accrue against the fund. Alternatively, the employer may be tempted to recover the surplus.

From the employer's standpoint, the purpose of the pension fund is to pay off the employer's pension promises. We have seen that the distinctive trait of a defined benefit pension plan, in comparison with a defined contribution plan, is that the employer bears the investment risk. ${ }^{154}$ Since the employer is responsible for paying the promised benefits and must make up the shortfall if the

${ }^{151}$ The losses to the fund may have been partially offset by an increase in employer contributions. Apparently, the level of contributions to the plan in the Walton case was a function of the number of covered hours worked. $609 \mathrm{~F}$ Supp at 1226. As the number of hours increased, however, so did the losses to the fund, because it was purchasing that much more higher priced labor.

${ }^{152}$ Dan M. McGill and Donald S. Grubbs, Jr., Fundamentals of Private Pensions 239-

63 (Irwin, 6th ed 1988).

${ }^{153}$ ERISA $\S 301$ et seq, 29 USCS $\S 1081$ et seq.

154 See text at notes $37-39$. 
plan becomes underfunded, the employer reasons that he should be able to recover the gain if the plan becomes overfunded. Indeed, the technique of ceasing contributions while creating new liabilities against an overfunded plan is an indirect way for the employer to spend the surplus.

ERISA, however, provides no direct mechanism for the employer to withdraw surplus assets from a continuing pension plan. It is unclear why the statute does not address this problem. The subject received scant attention in the drafting process. Overfunded plans were quite rare in the pre-ERISA period, and the Congressional staffs who worked on the early drafts of the legislation did not pay the matter much attention. To the extent that the drafters thought about it, they reckoned "that overfunded plans were the product of an excessive forfeiture rate among plan participants due to lack of adequate vesting," hence that ERISA's vesting provisions would cause "overfunded plans .... [to] disappear altogether."15s

Because ERISA does not expressly authorize the employer to withdraw surplus assets from an ongoing plan, the exclusive benefit rule would forbid such a withdrawal. ERISA's section 403(c)(1), sometimes called the "noninurement" version of the exclusive benefit rule, says that "the assets of a plan shall never inure to the benefit of any employer and shall be held for the exclusive purposes of providing benefits to participants in the plan and their beneficiaries." Evs Even though the purpose of this language may have been to prevent a pension plan from becoming underfunded, and hence insufficient to discharge its obligations, the statute does not speak in those terms. Thus, if an employer tried to write himself a check from the assets of an overfunded pension plan on the ground that the plan no longer needed all its money, the employer would surely violate the exclusive benefit rule.

Yet ERISA expressly authorizes the employer to recover surplus pension assets by another avenue-as an incident to the termination of the plan, when all accrued benefits and other liabilities have been paid. ${ }^{167}$ In the 1980s the practice of terminating a pen-

${ }^{155}$ Michael S. Gordon, Legislative and Regulatory History of the Asset Reversion Provision in ERISA 7 (unpublished paper, May 11, 1984), reprinted in Overfunded Pension Plans, Joint Hearing before the Select Committee on Aging and the Subcommittee on Labor-Management Relations of the Committee on Education and Labor, House of Representatives, 99th Cong, 1st Sess 89, 95 (1985) ("Overfunded Pension Plans").

${ }^{156}$ ERISA $\S 403(c)(1), 29$ USCS $\S 1103(c)(1)$, discussed in text at note 21.

${ }_{157}$ ERISA $\S 4044(d)(1), 29$ USCS $\S 1344$ (d)(1), provides for distributing to the employer "any residual assets of a single-employer plan" once "all liabilities of the plan to 
sion plan for the purpose of capturing the surplus (so-called "asset reversion") has become highly controversial. A trickle of such cases in the early years of ERISA attracted scant notice, ${ }^{158}$ but in 1981 two prominent firms - the publishing house of Harper \& Row and the A\&P grocery store chain-terminated their plans as part of major corporate restructurings. Those cases provoked lawsuits and Congressional hearings. ${ }^{159}$ Beginning in 1982, the runup in the stock and bond markets caused pension plan assets to experience a huge increases in value. The number of overfunded plans burgeoned, and so did the number of terminations whose purpose was to recapture the reversion for the employer. ${ }^{160}$

A firm that terminates an overfunded defined benefit plan frequently replaces the terminated plan with a new plan. Such a "termination/reestablishment" transaction has the effect of manipulating ERISA's termination provisions to achieve a result that resembles withdrawal of assets from an ongoing plan-just the power that ERISA does not grant to the employer, and that the exclusive benefit rule by its terms would forbid. A set of guidelines promulgated in 1984 by the so-called "ERISA Agencies" (the Department of Labor, the Pension Benefit Guaranty Corporation, and the Internal Revenue Service) facilitates termination transactions that are designed to offer substitute pension coverage for the employees. ${ }^{161}$ The rationale for the guidelines is that since the em-

participants and their beneficiaries have heen satisfied ...."Section 4044(d)(1) was amended in 1980 to exclude multiemployer plans.

${ }^{158}$ For example, In re C.D. Moyer Co. Trust Fund, 441 F Supp 1128 (E D Pa 1977), aff'd without opinion, 582 F2d 1273 (3rd Cir 1978), and also aff'd without opinion sub nom, Appeal of Pension Ben. Guaranty Corp., 582 F2d 1275 (3rd Cir 1978), discussed in text at notes 170-73.

138 Walsh v Great Atlantic \& Pacific Tea Co., Inc., 726 F2d 956 (3d Cir 1983); District 65, UAW v Harper \& Row, Publishers, Inc., 576 F Supp 1468 (S D NY 1983); Hearings before the Committee on Labor and Human Resources, United States Senate on Francis Xavier Lilly, of Maryland, to be Solicitor U.S. Department of Labor, S Hrg 98-1118, 98th Cong, 2d Sess (1984); Pension Asset Raids, Hearing before the Select Committee on Aging, U.S. House of Representatives, Committee Publication 98-438, 98th Cong, 1st Sess (1983).

${ }_{180}$ The Dow Jones Industrial Average advanced from a 1982 low of 776.92 on August 12 of that year to year-end highs of 1046.54, 1258.94, 1211.57, 1546.67, and 1895.95 in 19821986. On the decline in interest rates and the related bull market as one of the main causes of overfunding, see Statement of Jeremy Bulow, The Termination of Overfunded Pension Plans, in Overfunded Pension Plans at 256, 256-57 (cited in note 155). For data showing the increase in plan termination reversions over these years, see Gerald D. Facciani, Asset Reversion Policy-Past, Present and Future, in 1 Pension and Profit Sharing, 11105 , at 1214 (Prentice-Hall, 1986).

${ }_{181}$ The guidelines were issued May 23, 1984 (PBGC News Release 84-23) and reprinted in $\mathrm{CCH}$ Pension Plan Guide $110,185 \mathrm{~L}$, at 13,599-601 (CCH, 1988). For the Reagan Administration's view of the benign effect of the guidelines, see Statement of David M. Walker, Acting Executive Director, Pension Benefit Guarantee Corp., in Overfunded Pension Plans 
ployer has the undoubted power to terminate the plan and recapture the reversion without providing for replacement pension arrangements, it is better to encourage him to exercise his power to terminate the plan in a manner that results in substitute pension coverage for the employees.

The boom in terminating plans for asset reversion that occurred in the 1980s set off a political struggle that continues to the present day. Opponents of asset reversion, who tend to be allied with organized labor, would prohibit the employer from recapturing plan assets. The Reagan Administration has opposed that prohibition but supported a 10 percent tax on asset reversions, which was enacted as part of the Tax Reform Act of $1986,{ }^{162}$ and which was meant to discourage termination transactions. ${ }^{163}$

The present article is not the place to canvass the arguments about altering ERISA to restrict or prohibit asset reversion. ${ }^{164} \mathrm{We}$ wish to make quite a different observation about the experience

at 114-18 (cited in note 155).

${ }^{162}$ IRC $\$ 4980,26$ USCS $\$ 4980$ (Supp 1988). See generally Norman P. Stein, Taxing Reversions from Pension Plans, 35 Tax Notes 1131 (1987).

${ }^{163}$ Recently, the Administration has favored a proposal that would allow withdrawals from an ongoing plan, provided that the plan retains a contingency reserve 25 percent in excess of accrued henefits. For a brief description see Lee A. Sheppard, Administration Proposes to $U_{p}$ the Ante for Defined Benefit Plans, 34 Tax Notes 743, 745-46 (1987).

${ }^{164}$ The main issue is whether plan participants should have a larger claim than ERISA $\S 4044$ (d)(1) recognizes. Present law, as amplified by the ERISA Agencies' Guidehnes (cited in note 161), recognizes no interest beyond presently accrued benefits.

A terminating plan must pay off all accrued benefits, including those that are not yet vested and would be forfeitable if the participant were to terminate his employment. It has been argued, however, that employees expect benefit improvements over the course of employment, in part to compensate for future expected inflation, and that the presently protected accrued benefits understate the employees' expectations in the fund. The lawyer for the participants in the Harper \& Row case (discussed in text at notes 174-75) contended in Congressional testimony: "The crux of the matter is that ... participants and beneficiaries have a reasonable expectation that a defined benefit plan will be continued unless some legitimate business necessity compels the employer to abandon it." Michael S. Gordon, Statement, in Overfunded Pension Plans at 76 (cited in note 155). This expectation has been called an implied term of the pension contract, and the argument has been made that asset reversion violates that term. Ippolito, Pensions, Economics and Public Policy at 239, 250 (cited in note 39).

The great difficulty with this argument is that it begs the question of why so important a term would be left implicit rather than made explicit. The employees, who are often represented in pension negotiations by capable labor unions (such as the UAW in the Harper \& Row case) would seem to have every incentive to see to it that so important a term of the pension contract be spelled out. The persistent failure to spell out the term suggests that it does not exist.

Ippolito is wrong in suggesting (id at 250) that there is no effective legal mechanism by which a plan sponsor can contract away the right to the reversion of pension assets. See the cases cited in note 177 . 
with asset reversion under ERISA. Asset reversion is an area in which the statute has guided the courts to a straightforward and predictable case law, because ERISA expressly abridges the exclusive benefit rule to take account of the employer's interest in the pension fund. ERISA prefaces both the "sole interest/exclusive purpose" rule ${ }^{165}$ and the noninurement rule ${ }^{168}$ with provisos that himit both rules to circumstances not governed by section 4044 , (the provision whose subsection $(d)(1)$ authorizes asset reversion upon termination of the plan after all the plan's liabilities have been discharged). ${ }^{167}$

The typical asset reversion case involves a plan that contains the standard inflexible exclusive benefit and noninurement language $^{\mathbf{1 6 8}}$ (terms that facilitate tax qualification). The plan also provides (or is amended ${ }^{168}$ to provide) the employer with a power to terminate; the employer then exercises the power. In litigation, the plan participants, as plaintiffs, invoke the exclusive benefit rule; the employer trumps them by pleading his section $4044(\mathrm{~d})(1)$ authority. In the first asset reversion case to arise under ERISA, In re C.D. Moyer Co. Trust Fund, ${ }^{170}$ the court worked its way through the language of the plan and the statute and upheld the reversion as "consistent with the policies underlying the enactment of ERISA."171 The court's reasoning has proved influential ${ }^{172}$ in later cases. "Employers ... will not be penalized for overfunding in 'an abundance of caution' or as a result of a miscalculation on the part of an actuary. Thus, employees will continue to be protected to the extent of their specific benefits, but will not receive any windfalls due to the employer's mistake in predicting the amount necessary to keep the Plan on a sound financial basis."173

In District 65, UAW v Harper \& Row, Publishers, Inc., the

${ }^{265}$ ERISA $\S 404(a)(1), 29$ USCS $\S 1104(a)(1)$, discussed in text at notes 19-20.

${ }^{168}$ ERISA $\S 403(\mathrm{c})(1), 29$ USCS $\$ 1103(\mathrm{c})(1)$, discussed in text at note 21.

167 Extracted in note 157.

${ }^{168}$ See, for example, In re C.D. Moyer Co. Trust Fund, 441 F Supp 1128, 1131 (E D Pa 1977).

168 ERISA $\S 402(b)(3), 29$ USCS $\S 1102(b)(3)$, requires that every plan be amendable, and that the plan identify the persons who have authority to amend the plan.

170441 F Supp 1128 (E D Pa 1977).

171 Id at 1132.

172 See, for example, Washington-Baltimore Newspaper Guild v Washington Star Co., 555 F Supp 257, 260 (D DC 1983); see also Bryant v International Fruit Products Co., Inc., 793 F2d 118 (6th Cir 1986), cert denied, 479 US 986 (1986), rev'g 604 F Supp 890 (S D Ohio 1985), where both majority and dissent wrestled with the view developed in Moyer, quoted in text at note 173 , that allowing employees to capture the reversion in a defined benefit plan rewarded them with "windfalls."

${ }^{173}$ Moyer, 441 F Supp at 1132-33. 
court held "that the decision to terminate the [plan] is exempt from ERISA's fiduciary standards." 174 The court explained that both sections 403(c)(1) (noninurement) and 404 (sole interest/exclusive purpose) "contain exceptions when the challenged conduct involves termination."178 An employer can still lose an asset reversion case-by neglecting to preserve the power to recapture the assets $^{178}$ or by contracting the power away. ${ }^{177}$ But as a matter of ERISA law the employer is entitled to the reversion (now subject to the 10 percent tax), unless he waives that right, for example, by the terms of the plan or by the terms of a collective bargaining agreement or other contract. The Department of Labor, which oversees ERISA fiduciary law, "has consistently taken the position that the decision to terminate a pension plan is . . . a settlor, or business activity and is therefore not subject to ERISA's fiduciary duty requirements." 178 When asset reversion gives rise to litigation, therefore, the case usually turns on construction of the plan or contract, not on whether ERISA fiduciary law allows the reversion.

From the perspective of ERISA's exclusive benefit rule, we emphasize the irony of the experience with asset reversion. ERISA permits the employer to appropriate plan assets, the largest conceivable invasion of a trust fund, whereas it treats conduct that is much less threatening to the plan (such as the value-enhancing machinations of the defendants in Leigh $v$ Engle $)^{179}$ as being in breach of ERISA's fiduciary duties. This irony is, of course, easily explained. In the sphere of asset reversion, ERISA expressly limits the exclusive benefit rule to take account of the employer's interest in the pension assets.

\section{ESOPs}

The so-called stock bonus plan is a type of defined contribution plan in which the employer contributes company securities rather than cash to the individual accounts of the participating

174576 F Supp 1468, 1477 (S D NY 1983).

${ }^{175}$ Id at 1478 , citing the proviso that cross-references to, inter alia, ERISA $\S 4044,29$ USCS $\S 1344$.

${ }^{178}$ Audio Fidelity Corp. $v$ Pension Benefit Guaranty Corp., 624 F2d 513 (4th Cir 1980).

${ }^{177}$ A divided court in Bryant, 793 F2d 118, held that the employer had contracted away its reversion power. This rationale was also invoked in Delgrosso v Spang \& Co., 769 F2d 928 (3d Cir 1985).

${ }^{178}$ Opinion Letter of Dennis M. Kass, Assistant Secretary, U.S. Dept. of Labor, March 13, 1986, reprinted as Labor Department Letter on Fiduciary Responsibility and Plan Terminations, 13 Pension Rptr (BNA) 472 (1986).

${ }^{279} 727$ F2d 113 (7th Cir 1984), discussed in text following note 132. 
employees. In 1974 ERISA authorized a specially tax advantaged version, the employee stock ownership plan (ESOP). ${ }^{180}$ ESOPs have become prominent and problematic in a variety of settings. In the present article we touch upon a single dimension of the ESOP - the tension between it and the exclusive benefit notion.

The ESOP is best understood as a tool of corporate finance. The ESOP borrows money from a lender to buy employer stock from the employer. The employer guarantees to contribute enough money to the ESOP each year to permit the ESOP to service the debt and retire the principal amount of the loan. These annual contributions to the ESOP are fully tax deductible. Much as with debt financing, the employer has raised capital while effectively assuming the obligations to repay a loan. The advantage to an employer is that by utilizing an ESOP rather than conventional debt, the contributions to the ESOP are fully deductible, including the portion of the contribution that is functionally the equivalent of the repayment of principal on the loan. The ESOP thereby enables "the corporation to finance its capital requirements with pre-tax dollars."181

Increasing the employee's holdings of stock in his employer through ESOPs has been lauded as people's capitalism. Related claims made on behalf of ESOPs are that they increase savings and productivity, save jobs, and redistribute wealth. ${ }^{182}$ One indication that such claims are overblown is that employees have not much valued the supposed advantages of ESOPs. ${ }^{183}$ In fact, despite repeated exhortations and efforts to promote employee share ownership, stock bonus plans were relatively unimportant until ERISA created tax subsidies to encourage employers to impose the ESOP version upon employees.

A pair of major drawbacks help explain why employee stock ownership plans do not succeed without subsidy. First, a well known incentive problem exists when a firm (particularly a large firm) has workers as residual claimants. When non-employee

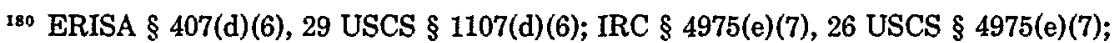
see generally D. Bret Carlson, ESOP and Universal Capitalism, 31 Tax L Rev 289 (1976).

${ }_{181}$ Employee Stock Ownership Plans: An Employer Handbook, Committee Print 96-25, 96th Cong, 2d Sess 23 (1980) (prepared by the staff of the Committee on Finance, US Senate).

182 See the critique by D. Bret Carlson, ESOP and Universal Capitalism, 31 Tax L Rev 289, 289-93 (1976).

${ }^{183}$ For a discussion of why the claimed benefits of ESOPs are illusory, see Richard L. Doernberg \& Jonathan R. Macey, ESOPs and Economic Distortion, 23 Harv J Leg 103 (1986). 
shareholders are the residual claimants, they (and the managers representing their interest) tend to choose investment projects that maximize the value of the firm. ${ }^{184}$ When, however, employees are the residual claimants, they behave differently. Consider the situation in which the firm must decide whether to invest in a new labor saving technology that will reduce the cost of production. Shareholders will find it in their interest to implement the new technology but employees who might lose their jobs as a result might oppose the investment. Thus, the shareholder owned firm would adopt the efficient course of action while the employee owned firm might not. Because employee ownership tends to be inefficient, firms are rarely organized in this manner in the absence of subsidy or regulatory intervention. ${ }^{185}$

A second major drawback to an employee owned firm is that employees are inefficient risk bearers. The employee already has much of his wealth-his human capital-tied up in the firm where he works. If the employee is as risk averse as most of us, he should invest the remainder of his wealth away from the employing firm, in order to minimize risk. Investing further in the firm where he works needlessly magnifies the intrinsic underdiversification of the employment relationship. Shareholders, by contrast, are much more efficient risk bearers, because by buying into or assembling a diversified portfolio of securities, the shareholder can virtually eliminate the firm-specific risk.

ERISA imposes a duty to diversify on pension fiduciaries, ${ }^{186}$ but suspends it for ESOPs. Thus, to the extent that ERISA and the tax code promote ESOPs, the law is creating incentives for firms to pressure employees to bear excessive and uncompensated risk. ${ }^{187}$

The severe confiicts of interest that frequently arise when the ESOP trustees are representatives of management further highlight the tension between ESOPs and the exclusive benefit rule. In leveraged buy-outs involving ESOPs, for example, the ESOP trustees must decide how much the ESOP should pay for employer stock. Since the trustees typically represent (or are themselves)

184 See Eugene F. Fama and Michael C. Jensen, Organizational Forms and Investment Decisions, $14 \mathrm{~J}$ Fin Econ 101 (1985) for a discussion of this point.

${ }^{185}$ The economics of labor owned firms is analyzed in Michael C. Jensen and William H. Meckling, Rights and Production Functions: An Application to Labor-managed Firms and Codetermination, $52 \mathrm{~J}$ Bus 469 (1979).

188 ERISA § 404(a)(1)(C), 29 USCS § 1104(a)(1)(C).

${ }^{187}$ See Richard Brealey and Stewart Myers, Principles of Corporate Finance, ch 7-8 (McGraw-Hill, 2d ed 1984), noting that diversifiable risk is uncompensated. 
selling shareholders, the conflict of interest is intense. ${ }^{188}$

ESOPs, in short, are impossible to reconcile with the exclusive benefit rule. The tax subsidy associated with ESOPs may be valuable to the firm, but is in no way targeted to employees. Moreover, ESOPs create inefficient incentives, force workers to bear unnecessary risk, and subject them to the perils of self-dealing transactions.

\section{Toward a Sensible Interpretation of the Exclusive BENEFIT RULE}

To say that somebody is a fiduciary, Justice Frankfurter pointed out long before there was an ERISA, "only begins analysis; it gives direction to further inquiry. To whom is he a flduciary? What obligations does he owe as a fiduciary?"189 The problem of defining the appropriate scope of fiduciary duties is particularly acute in ERISA. Despite the exclusive benefit rule, there is nothing exclusive about employees' interests in pension and welfare benefit plans. These plans are complex multiparty arrangements, and it was unwise for ERISA to attempt to capture the complex responsibilities of plan flduciaries by analogy to the simpler world of the private gratuitous trust.

In an employee beneflt plan, depending upon the type and condition of the plan, the fiduciary may owe duties not only to the "participants and their beneficiaries," as ERISA's exclusive benefit rule mandates, ${ }^{190}$ but also to the employing firm and its shareholders, to the revenue authorities, and to the federal pension insurer, the PBGC. Moreover, as we have been at such pains to point out, within the class of participants that ERISA's exclusive benefit rule does identify, there are frequent conflicts of interest, especially between older and younger employees and between retirees and active employees.

In this section, we focus on the two recurrent problems that we have addressed throughout: (1) the employer as beneficiary; and (2) conflicts among employees. We demonstrate that the exclusive benefit rule, properly interpreted, should permit a trustee, and ultimately a reviewing court, to recognize these realities of the modern pension trust.

${ }^{188}$ ERISA $\S 406,29$ USCS $\S 1106$, ordinarily prohibits transactions between pension plans and other interested parties such as large stockholders, but ERISA $\$ 407(\mathrm{~d})(3)(\mathrm{A})(\mathrm{ii})$, 29 USCS $\$ 1107(\mathrm{~d})(3)(\mathrm{A})(\mathrm{ii})$, allows these deals for ESOPs.

${ }^{189}$ SEC v Chenery Corp., 318 US 80, 85-86 (1943).

190 ERISA § 404(a)(1), 29 USCS § 1104(a)(1). 
A. The Employer as Beneficiary

The purpose of ERISA is to protect retirement security for employees. This statutory purpose, coupled with the language of the exclusive benefit rule that focuses solely on employees' interests, appears to preclude recognition of the employer as a beneficiary. As a result, courts have been forced to indulge in pretense, such as the notion that benefits to employers are merely "incidental," in order to reconcile ERISA with the economic realities of the multiparty pension plan.

We believe that ERISA permits the courts to be more forthright in recognizing the employer's interest as beneficiary. ERISA empowers the employer or other sponsor to create, amend, and terminate plans, to name the fiduciaries, and to recapture excess assets. These statutory powers evince that pension and benefit plans embody the interests of employers as well as employees. Moreover, it is a mistake to view a pension plan as a zero sum game, in which an action that benefits the employer automatically harms the employees. On the contrary, from the ex ante perspective, the interests of employer and employees converge. ${ }^{191}$ The correct interpretation of fiduciary duties is the rule that maximizes the joint welfare of both.

For the same reason, the exclusive benefit rule should not be interpreted to mean that the trustee should decide all controversies between employees and the employer in favor of the employees. Such a rule would benefit particular complaining employees ex post, but it would operate to the detriment of employees as a class ex ante. A rule favoring employees that overrides the initial understanding between the parties, whether explicit or implicit, will actually harm employees by discouraging plan formation.

We do not mean to suggest that the employer's interests will always be compatible with those of employees. Once the initial agreement is concluded, either party may have an incentive to behave opportunistically. When the trustee is a representative of the employer, opportunistic behavior by the employer is of particular concern. We have discussed why the decision to deny plan benefits following severance of the employment relationship with a class of employees has an overtone of opportunistic behavior by the employer. ${ }^{192}$

Frequently it will be difficult to tell whether a given action is 
consistent with the ex ante understanding between the parties or represents ex post opportunistic behavior by the employer. Our discussion of the trustee's decision in Morse $v$ Stanley to deny benefits to the employees who quit their jobs and joined a competitor illustrates this problem. Recognition of the importance of the ex ante perspective will not automatically transform ERISA fiduciary law from a hard field to an easy one. Often, the issues in pension and welfare benefit plans will remain complex. But hard problems are much more likely to be solved properly when the governing rule takes account of the relevant interests.

\section{B. Conflicts Among Employees}

The language of the exclusive benefit rule speaks in the plural. It stipulates that a duty of loyalty is owed to "participants and their beneficiaries." It does not assume, as it could not logically assume, that all participants and their beneficiaries will always have the same interests. We have discussed how takeover and social investing cases frequently involve conflicts between different classes of employees.

The problem in these situations is different from cases in which the employer may be acting opportunistically. Because the conflict is between classes of employees, not between the employer and employees, opportunistic behavior by the employer is not the issue. Nevertheless, some mechanism must exist for resolving conflicts among employees, even when the statute overlooks the problem.

Conventional trust law recognizes the problem of conflicts among beneficiaries, such as the tension between successive beneficiaries (life tenant and remainderman), by means of the duty of impartiality. ${ }^{193}$ The duty of loyalty abides in the sense that self dealing is equally forbidden when there is one beneficiary or many. But the duty of loyalty is owed to all the beneficiaries. Thus, the law of trusts recognizes that the concept of "exclusive benefit" makes no sense when the interests of some beneficiaries conflict with the interests of others. In ERISA, by contrast, there is no express analogne to the duty of impartiality. The statute speaks of the exclusive benefit of the employees.

Nevertheless, the duty of impartiality inheres in the logic of

193 "When there are two or more beneficiaries of a trust, the trustee is under a duty to deal impartially with them." Restatement $\S 183$ (cited in note 17); see also id, $\S 232$ (impartiality between successive beneficiaries). 
pension trusts. The duty should be spelled out, ideally as a matter of legislative amendment, but more practically-in the course of fiduciary administration and litigation-as an implied component of ERISA fiduciary law. Recognizing an implied duty of impartiality would not entail a major extension of current law. Consider Winpisinger $v$ Aurora Corp. ${ }^{194}$ in which the issue was which group of employees should be affected by a permitted cancellation of past service credits undertaken for the purpose of protecting the fund. The plan trustees decided to cancel the past service credit of one group of employees but not another. The court, however, concluded that this action was discriminatory and held that the fiduciary duty of the trustees required that the trustees exercise discretion in dealing with different classes of employees in a nondiscriminatory way. ${ }^{195}$

The logic of Winpisinger has broad applicability. The fundamental principle of the case-that trustees cannot act to benefit one group of beneficiaries at the expense of another-is essentially the duty of impartiality that requires the multiphcity of interests to be kept in constant consideration. The same principle could be applied profitably to takeover and social investing situations which, as we have discussed, so frequently involve conflicts among beneficiaries.

Recognition of a duty of impartiality, like recognition of the employer's interest, will not turn hard cases into easy ones. It will, however, promote conceptual clarity by insisting that, when pension and benefit plan administration does entail conflicts of interest among employees, the conflicting interests should be admitted and evaluated rather than ignored.

194456 F Supp 559 (N D Ohio 1978).

195 Id at 569 . The court expressly relied on antidiscriminatory language that was included in the plan agreement to qualify for tax benefits. See the discussion of the antidiscrimination norm in text at notes 64-65. While the antidiscrimination norm is troublesome when used to interfere with the employee's choice in joining in a plan, it could sensibly be interpreted as a statutory duty of impartiality. 